\title{
Strategy of Internationalization by Ukrainian Meat Producers' Implementation
}

\author{
By Alona Tanasiichuk ${ }^{1}$, Olha Hromova ${ }^{2}$, Anastasiia Abdullaieva ${ }^{3}$, \\ Yulia Holovchuk ${ }^{4}$, Kateryna Sokoliuk ${ }^{5}$
}

\begin{abstract}
Scientific and methodical approaches to the definition of international markets for implementation of the strategy of internationalization by Ukrainian meat producers' have been developed, choosing strategy of internationalization by Ukrainian meat producers procedure has been determined, a system of indicators has been developed to assess the marketing appeal of new international markets for Ukrainian meat producers. According to the analysis of practical aspects results of the agrarian enterprise and its associations functioning, a scientific and methodical approach to the integrated assessment of the business environment of international markets attractiveness' for Ukrainian meat producers by the product group "0207 Poultry Meat" was developed. The proposed approach is based on applying summing up the ranks to rank foreign markets according to the system of dynamic indicators method, which allowed determining the marketing attractiveness of the new international markets for the activity of Ukrainian meat producers in these markets. As a result of the proposed approach application, foreign markets have been identified that demonstrate favorable conditions for doing business with Ukrainian meat producers. It has been proved that the markets of Denmark and Finland have demonstrated favorable conditions for doing business with them, which testifies that internationalization of Ukrainian meat producers' strategy should be aimed at the formation of future outlines of new markets in the direction which is beneficial to them.
\end{abstract}

Keywords: international business activities, internationalization strategies, attractiveness of international markets marketing, a system of indicators for assessing the marketing attractiveness of new international markets.

\section{Introduction}

The current stage the world economy development is characterized by globalization processes intensification and the deepening of economic integration between countries. This causes an increase in the international activity of Ukrainian meat producers that are actively moving to foreign markets.

During the international marketing environment development, Ukrainian meat producers have to solve new and complex tasks related to: adapting to unusual business conditions; defining the perspectives and threats that may arise before the enterprise in

\footnotetext{
${ }^{1}$ Doctor of Economics Sciences, Associate Professor of the Department of Marketing and Advertising, Vinnytsa Institute of Trade and Economics of KNUTE, Ukraine.

${ }^{2} \mathrm{Ph} . \mathrm{D}$. in Economics, Associate Professor of the Marketing and Advertising Department, Vinnytsa Institute of Trade and Economics of KNUTE, Ukraine

${ }^{3} \mathrm{Ph} . \mathrm{D}$. in Economics, Assistant of the Finance Department, Vinnytsa Institute of Trade and Economics of KNUTE, Ukraine

${ }^{4} \mathrm{Ph} . \mathrm{D}$. in Economics, Senior Lecturer of the Department of Marketing and Advertising, Vinnytsa Institute of Trade and Economics of KNUTE, Ukraine

${ }^{5} \mathrm{Ph} . \mathrm{D}$. in Economics, Senior Lecturer of the Department of Marketing and Advertising, Vinnytsa Institute of Trade and Economics of KNUTE, Ukraine
} 
the new markets, determining the way of access to them; studying the level of activity of foreign competitors; overcoming meat producers' dependence on the domestic market; increasing the efficiency of sales activities by strengthening their market positions; the price policy stabilization on the domestic and foreign markets, by applying a degression to the quantity of products; the problem of dependence of Ukrainian meat producers on seasonal fluctuations solution in demand in international markets, which is especially relevant to them.

The problem of activating activities of Ukrainian meat producers' is very up-to date by means of international marketing under the new economic conditions which has determined the choice of research topic.

The aim of the study is to assess the meat market world's export potential, justifying the need to introduce a strategy for internationalization by Ukrainian meat producers.

\section{Literature Review}

Different aspects of the strategy implementation of internationalization are considered in numerous works of foreign and domestic scientists. Such researches should include the work of Golubkova E. (2003) [1], Kotler F., Keller K. (2008) [2], Robertson R. (2003) [3], Ollivier A., Diana A., Ursa R. (1993) [4] and Ukrainian specialists: Voychak A., Shumeiko V. (2009) [5], Gerchikova I. (2000) [6], Pavlenko AF (2008) [7], Tsigankova T. (2001, 2004) [8, 9], Kovinko O. [10] etc., who study some theoretical and practical aspects of the international marketing environment study, factors influencing the choice of international markets, opportunities and barriers for enterprises to penetrate foreign markets and ways of timely adaptation them. The problems of choosing and analyzing strategies for the internationalization of enterprises are devoted the works of Backhaus K., Voeth M. (1996) [11], Hoskisson R., Hitt M. (1984) [12], Rumelt R. (1974) [13], Kotler F., Berger R., Bikhoff N. 2016) [14], etc. The imperfection of theoretical and methodological support, the lack of practical experience of agrarian enterprises internationalizing activities, the problems and prospects of Ukrainian meat producers' internationalization need further research.

\section{Research Methodology}

The prerequisite for introducing by Ukrainian meat producers' a strategy for internationalization is the study of the export potential of world markets, in particular the assessment of international markets potential for meat, the demand for agrarian production in international markets study, and the definition of the prospects for changing demand for meat. In order to assess the export potential of world markets, it is necessary to apply special measuring methods: to assess current potential and current demand - analysis of various types of trading statistics according to different countries of the world; to assess the current potential of the enterprise - an analysis of the necessary information on the results of activities; to assess the Ukrainian meat producers' prospective potential and the prospects for demand in the meat market - time series analysis, statistical estimation of demand, expert evaluation. For the final choice of the international market it is used the matrix of " market attractiveness - opportunities of the 
enterprise (competitive positions)", that is a multifactor portfolio matrix.

Applying scientific and methodological approaches for Ukrainian meat producers' evaluation and selection of international markets requires the pre-selection of markets, the definition of a market segment and criteria for their attractiveness, and competitive position of Ukrainian meat producers assessing. However, there is no need to conduct export-import research in all markets of the world. It is enough to highlight the most important markets for partners - exporters and importers, the analysis is conducted in the following sequence (Fig. 1).

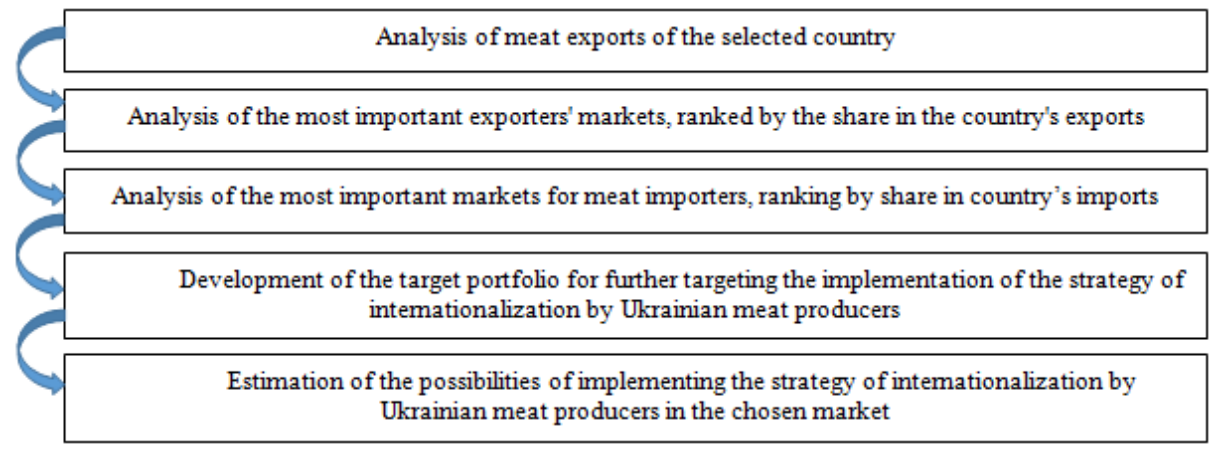

Figure 1. Definition stages of international markets for implementation internationalization strategy by Ukrainian meat producers on them.

Source: the author's own development

Important criteria for assessing the competitive situation in the market of selected countries is the market attractiveness in terms of capacity and intensity of competition on it. All Ukrainian meat producers and suppliers can use the market portfolio as a benchmark for making long-term marketing decisions.

Based on the initial market portfolio, taking into consideration all the chances and risks in the international markets of certain countries, the strengths and weaknesses of its own production and marketing potential, Ukrainian meat producers can develop the target or desired market, thus desired market porphyry, defining goals and benchmarks for future marketing strategies while selling meat on international markets (Fig. 2).

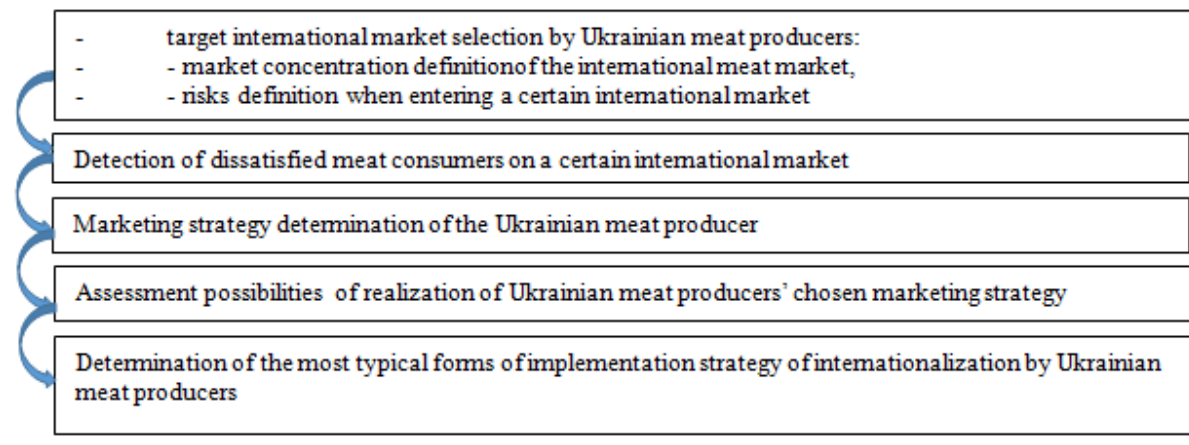

Figure 2. The procedure for choosing a strategy for internationalization by Ukrainian meat producers Source: the author's own development * 
The final decision on the choice of international markets and relevant marketing strategies on each of them depends on the results of evaluating the marketing appeal of new international markets for Ukrainian meat producers according to dynamic indicators defined system (Fig. 3).

Indicators of the country's ntemational potential of intemational tra de integration

Indicators for assessing the economic potential of intemational trade cooperation between countries

Indicators of the intemational trade potential of the target industry in target markets

Indicators of bilateral tra ding potential of partner countries

Indicators of business environment attractiveness of the target countries

Figure 3. A system of indicators for assessing the marketing attractiveness of new international markets for Ukrainian meat producers

Source: the author's own development

Consequently, the effectiveness of the process of implementing by Ukrainian meat producers' internationalization strategy depends on the existing differences in potential, the rates of development of the countries' markets under study and the chances of overcoming the gap in their main indicators. During expert evaluation of the marketing attractiveness indicators new international markets for Ukrainian meat producers, it is necessary to select the markets of foreign countries, which will have the indicators as close as possible to the Ukrainian economy, the result of evaluation will allow us to draw conclusions about the possibilities of implementing the strategy of internationalization by Ukrainian meat producers.

\section{Results of the Study}

Under modern conditions of managing agrarian enterprises, it is important to carry out a detailed selection of target markets, which involves assessing their compliance with the resources and Ukrainian producers' competitive advantages. Also, at this stage, they make a marketing decision to implement the internationalization strategy, geographic concentration of resources in a limited number of similar markets or diversification of resources in a large number of different markets.

Not every enterprise can afford to cover simultaneously a large number of countries. Decisions on the concentration of resources in a limited number of similar markets or diversification of resources in a large number of different markets should be taken with a large number of factors listed in Chart. 1 (Akulich M.V., 2006) [15]. 
Chart 1. Factors determining the geographical concentration of Ukrainian meat producers' resources

\begin{tabular}{|c|c|c|}
\hline Group of factors & $\begin{array}{l}\text { Factors contributing to } \\
\text { concentration in international } \\
\text { markets }\end{array}$ & $\begin{array}{l}\text { Factors contributing to } \\
\text { diversification in international } \\
\text { markets }\end{array}$ \\
\hline $\begin{array}{l}\text { Factors relating to } \\
\text { Ukrainian meat } \\
\text { producers }\end{array}$ & $\begin{array}{l}\text { Low risk management } \\
\text { awareness } \\
\text { Ability to select "best markets". }\end{array}$ & $\begin{array}{l}\text { High degree of risk management } \\
\text { awareness } \\
\text { Lack of knowledge about markets. }\end{array}$ \\
\hline $\begin{array}{l}\text { Factors related to the } \\
\text { product group "02 Meat } \\
\text { and } \\
\text { Edible By-products » }\end{array}$ & $\begin{array}{l}\text { Product with unlimited scope. } \\
\text { Product that is re-purchased. } \\
\text { The middle of the LCT. } \\
\text { A product that needs to be } \\
\text { adapted to different markets. }\end{array}$ & $\begin{array}{l}\text { The product has a limited scope. } \\
\text { A product that is not re-purchased. } \\
\text { Early or late stage of LCT. } \\
\text { A standard product that does not } \\
\text { require adaptation to different } \\
\text { markets. }\end{array}$ \\
\hline $\begin{array}{l}\text { Factors relating to the } \\
\text { meat market }\end{array}$ & $\begin{array}{l}\text { Large markets are not saturated } \\
\text { with competition. } \\
\text { Mature markets. } \\
\text { Key markets are divided among } \\
\text { many competitors. } \\
\text { High growth rate of each } \\
\text { market. } \\
\text { High loyalty of consumers. } \\
\text { Long term product } \\
\text { reproduction the by } \\
\text { competitors. }\end{array}$ & $\begin{array}{l}\text { Big markets are full of competition. } \\
\text { New markets or markets at the } \\
\text { LCT's Downfall. } \\
\text { Key markets are divided between } \\
\text { several strong competitors. } \\
\text { Low growth rate of each market. } \\
\text { Low consumer loyalty. }\end{array}$ \\
\hline Marketing factors & $\begin{array}{l}\text { High communication costs for } \\
\text { additional markets. } \\
\text { High costs for ordering } \\
\text { additional markets orders. } \\
\text { High physical distribution costs } \\
\text { for additional markets. }\end{array}$ & $\begin{array}{l}\text { Low communication costs for } \\
\text { additional markets. } \\
\text { Low cost orders for additional } \\
\text { markets processing. } \\
\text { Low costs for additional markets } \\
\text { physical distribution. } \\
\text { Standardized communication tools } \\
\text { in many markets. }\end{array}$ \\
\hline
\end{tabular}

Source: (Akulich M.V., 2006)[15].

Let's investigate the state and prospects for the development of the meat products market. Meat products are consumed by almost the entire population, regardless of age and sex. In general, meat is the source of irreplaceable amino acids, iron and vitamins of group B (niacin, choline, riboflavin, vitamin B6, vitamin B12). Iron is especially important for a person. It is difficult to obtain in sufficient quantities from plant products. Therefore, the research of meat products market is up to date (Sabluk P.T., 2008) [16].

In the world meat production structure, pork is the first place, the second place is poultry, the third place is beef, and the fourth is lamb (fig. 4). 


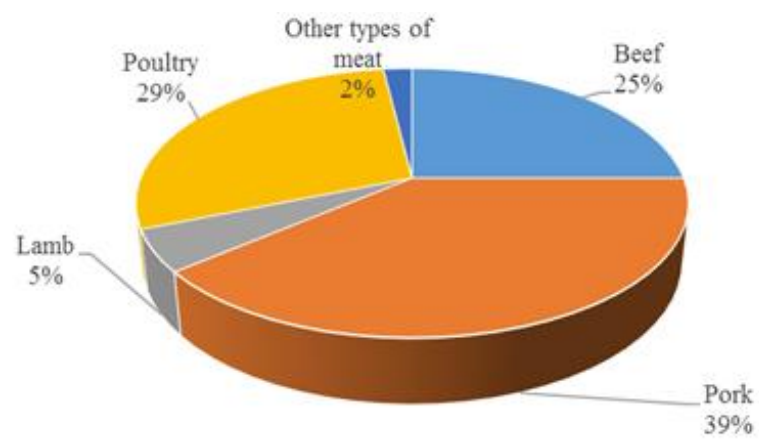

Figure 4. The structure of world meat production, 2016 (State Statistics Committee of Ukraine) [17]

In 2017, in the structure of world production of meat in 2017, the first place was poultry meat, the second and third - pork and beef (fig. 5).

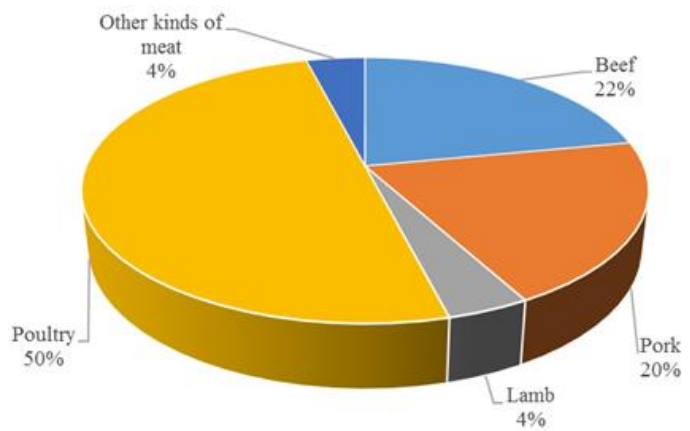

Figure 5. The structure of world meat production, 2017 (State Statistics Committee of Ukraine) [17]

In the world trade of beef and veal, exporters and importers of these products are clearly distinguished by regions of the main countries. Thus, Australia and New Zealand (over $25 \%$ of world supplies), as well as Brazil, Argentina, Uruguay, the EU and the USA are the export leaders. The main importers of their products are Japan, the Republic of Korea, Iran, Egypt.

World export of pork is 5095.3 thousand tons, of which the largest part belongs to Europe - 74,1\%. The main exporter is Denmark - 951 thousand tons (18.7\%), followed by the Netherlands - 635 thousand tons (12.5\%). Other exporting countries sell less than 500 thousand tons each and have a share in world exports of less than 10\% (State Statistics Committee of Ukraine) [17].

The main exporters of lamb and mutton are New Zealand and Australia. By exports of poultry the countries of the EU and the USA are allocated. The level of meat production and consumption is one of the main indicators of food security in the country. According to the State Statistics Service, consumption of meat per capita in Ukraine in 2015 amounted to $50 \mathrm{~kg}$, in 2016 it decreased by $4 \%$ - to $48 \mathrm{~kg}$, in 2017 it increased by $8 \%-54 \mathrm{~kg}$. In addition, cheaper types of meat and sausage products (Agravery agrarian news agency) are increasingly in demand [18].

Chicken currently accounts for almost $50 \%$ of the meat consumption structure. Meat 
exports in 2015 increased by 19\%, and according to preliminary estimates, the annual figure will be 245.6 ths. Tons. The largest share in its structure, namely $73 \%$, is chicken. However, in 2015, rapid growth has demonstrated exports of pork, which has increased by almost 4 times (Agravery agrarian news agency) [18].

In January-August 2015, the main exporting countries of poultry from Ukraine are Iraq $(26 \%)$, the Netherlands (15\%) and Germany $(7 \%)$.

In 2016, during January-September, the production of meat (live weight) amounted to 2276.0 thousand tons in Ukraine, in 2017 the volume of meat production in JanuarySeptember amounted to 2267.2 thousand tons, in 2018 - 2275.5 thousand tons (Chart 2). According to the data of Chart 2, in 2016 in Ukraine in January-September, compared to the corresponding period of 2015, meat production (live weight) increased by 5.1 tons or by $0.3 \%$. In 2017 , during this period, the production of meat (in live weight) decreased by 9 thousand tons, in 2018 the meat production increased by 8.8 thousand tons compared to the results for this period in 2017 (Agrarian news agency Agravery) [18]. As for the structure of foreign trade of meat in Ukraine, during the period from January to September 2016, meat exports amounted to 231254.5 thousand UAH, and imports in its turn - 48300.5 thousand UAH. (State Statistics Committee of Ukraine) [17].

Chart 2. Production of meat (live weight) in Ukraine, 2016-2018 pp. ${ }^{1}$ (State Statistics Committee of Ukraine) [17]

\begin{tabular}{|l|c|c|c|c|c|c|}
\hline & \multicolumn{2}{|c|}{ Meat (live weight) in 2016 } & \multicolumn{2}{l|}{ Meat (live weight) in 2017 } & \multicolumn{2}{c|}{ Meat (live weight) in 2018 } \\
\cline { 2 - 7 } & thousand & $\begin{array}{c}\text { in\% of the } \\
\text { corresponding } \\
\text { period of 2015 }\end{array}$ & $\begin{array}{c}\text { thousand } \\
\text { tons }\end{array}$ & $\begin{array}{c}\text { in\% to the } \\
\text { corresponding } \\
\text { period of 2017 }\end{array}$ & $\begin{array}{c}\text { thousand } \\
\text { tons }\end{array}$ & $\begin{array}{c}\text { in\% to the } \\
\text { corresponding } \\
\text { period of 2018 }\end{array}$ \\
\hline January & 287,2 & 97,7 & 298,8 & 104,0 & 300,0 & 100,4 \\
\hline $\begin{array}{l}\text { January - } \\
\text { February }\end{array}$ & 536,2 & 99,5 & 538,2 & 100,4 & 536,9 & 100,0 \\
\hline $\begin{array}{l}\text { January- } \\
\text { March }\end{array}$ & 793,6 & 100,8 & 793,9 & 100,0 & 790,4 & 99,7 \\
\hline $\begin{array}{l}\text { January- } \\
\text { April }\end{array}$ & 1111,6 & 102,6 & 1099,5 & 98,9 & 1084,1 & 98,7 \\
\hline $\begin{array}{l}\text { January- } \\
\text { May }\end{array}$ & 1334,1 & 101,4 & 1340,2 & 100,5 & 1325,9 & 99,1 \\
\hline $\begin{array}{l}\text { January- } \\
\text { June }\end{array}$ & 1559,1 & 101,0 & 1563,9 & 100,3 & 1550,5 & 99,4 \\
\hline $\begin{array}{l}\text { January- } \\
\text { July }\end{array}$ & 1780,3 & 101,2 & 1788,2 & 100,4 & 1778,4 & 99,7 \\
\hline $\begin{array}{l}\text { January- } \\
\text { August }\end{array}$ & 2012,4 & 101,1 & 2018,2 & 100,3 & 2014,6 & 100,1 \\
\hline $\begin{array}{l}\text { January- } \\
\text { September }\end{array}$ & 2276,0 & 100,3 & 2267,7 & 100,1 & 2275,5 & 100,3 \\
\hline
\end{tabular}

1 Excluding the temporarily occupied territory of the Autonomous Republic of the Crimea, the city of Sevastopol and part of the area of the anti-terrorist operation.

Taking into consideration the Chart 3, it can be concluded, in 2016 the volume of meat exports in comparison with 2015 increased by $2.7 \%$; imports decreased by $19.7 \%$; in 2017, meat exports increased by 37\% compared with the corresponding period in 2016; 
imports also increased by 38.7\%. In 2018 (January-August), exports increased by 17.8\% compared to 2017 (January-August). As for the import, an increase was made by 73.8\% (State Statistics Committee of Ukraine) [17].

Chart 3. Structure of Foreign Trade in Meat in Ukraine 1, 2014-2018 (State Statistics Committee of Ukraine) [17]

\begin{tabular}{|l|c|c|c|c|}
\hline Years & $\begin{array}{c}\text { Export } \\
\text { (thousand } \\
\text { dollars) }\end{array}$ & $\begin{array}{c}\mathrm{n} \% \text { to the } \\
\text { corresponding } \\
\text { period before. Year }\end{array}$ & $\begin{array}{c}\text { Imports } \\
\text { (thousand } \\
\text { dollars) }\end{array}$ & $\begin{array}{c}\text { in } \% \text { to the } \\
\text { corresponding } \\
\text { period before. Year }\end{array}$ \\
\hline 2014 & 381775,3 & 109,6 & 239230,9 & 38,7 \\
\hline 2015 & 377668,3 & 98,9 & 99338,4 & 41,5 \\
\hline 2016 & 387791,9 & 102,7 & 80773,4 & 81,3 \\
\hline 2017 & 531240,1 & 137,0 & 112024,7 & 138,7 \\
\hline 2018 (January-August) & 363363,8 & 117,8 & 86059,6 & 173,8 \\
\hline
\end{tabular}

${ }^{1}$ Excluding the temporarily occupied territory of the Autonomous Republic of the Crimea, the city of Sevastopol and part of the area of the anti-terrorist operation.

According to the ranking, which has been compiled by the agricultural portal Latifundist in Ukraine, there were identified leaders who are directly involved in the presentation of meat products not only in Ukraine but also in the world market (Chart 4).

Chart 4. TOP 10 meat processors of Ukraine in 2017 (Latifundist National Agroportal) [19]

\begin{tabular}{|c|l|c|}
\hline № & Name of Enterprise & Market share, $\%$ \\
\hline 1 & Myronivsky Hliboproduct & 13,5 \\
\hline 2 & ATB Corporation & 11 \\
\hline 3 & Globinsky meat processing plant & 9,6 \\
\hline 4 & Yatran & 4,6 \\
\hline 5 & Ermak Gold & 4,3 \\
\hline 6 & SMK Group of Companies & 3,9 \\
\hline 7 & APK INVEST & 3,2 \\
\hline 8 & Zhytomyr meat processing plant & 3,2 \\
\hline 9 & Taurus Plus & 3,0 \\
\hline 10 & Kremenchug meat & 2,9 \\
\hline
\end{tabular}

Almost all the mentioned above meat producers are determined by high-quality production, using the latest equipment. The reasons for reducing the land bank by Ukrainian agroholdings were different (Chart 5).

Chart 5. Leaders' of agrarian enterprises in Ukraine characteristics by the Land Bank, 2015-2017, thousand ha $[20,21]$

\begin{tabular}{|l|c|c|c|}
\hline \multirow{2}{*}{ Name of Enterprise } & \multicolumn{3}{|c|}{ Land volume, thousand hectares } \\
\cline { 2 - 4 } & 2015 & 2016 & 2017 \\
\hline \multicolumn{1}{|c|}{1} & 2 & 3 & 4 \\
\hline UkrLandFarming & 654 & 605 & 605 \\
\hline Agroproperty & 430 & 430 & 430 \\
\hline Kernel & 390 & 385 & 602,5 \\
\hline Myronivsky Hliboproduct & 360 & 370 & 370 \\
\hline
\end{tabular}




\begin{tabular}{|l|c|c|c|}
\hline \multirow{2}{*}{ Name of Enterprise } & \multicolumn{3}{|c|}{ Land volume, thousand hectares } \\
\cline { 2 - 4 } & 2015 & 2016 & 2017 \\
\hline \multicolumn{1}{|c|}{1} & 2 & 3 & 4 \\
\hline Astarta & 245 & 250 & 250 \\
\hline Ukrainian agrarian investments & 240 & 220 & - \\
\hline Harv East & 197 & 97 & 97 \\
\hline Dream Agroholding & 180 & 185 & 185 \\
\hline Industrial Dairy Company & 136,7 & 137 & 137 \\
\hline Agrain & 100 & 127 & 127 \\
\hline Ukrprominvest-agro & 122 & 122 & 122 \\
\hline Agro Generation & 120 & 120 & 120 \\
\hline Privat - Agro holding & 110 & 100 & 100 \\
\hline Agroton & 108 & 151 & 151 \\
\hline Ukragroprom & 107 & 107 & 107 \\
\hline
\end{tabular}

Source: Formed by (Eurasian Development Bank) [20, 21]

One of the main reasons for the land bank reduction of was fighting in Donetsk and Lugansk region. In particular, UkrLandFarming lost control over a part of land resources in the Donetsk and Luhansk regions, as well as over the "Red Flag" and "Interbusiness" poultry farms. Among other objective reasons, it is possible to distinguish the difficulties of access to financial resources, devaluation processes, the closure of certain external markets for livestock products (the 5 largest agricultural companies in Ukraine by the size of the land bank).

It is much more interesting to analyze the results of activity of leaders-agroholdings in Ukraine on the indicator of efficiency in agrarian business - income from sales of products (Chart 6).

Chart 6. Formation of of leaders-agroholdings rating in Ukraine on income from the sale of agrarian products, (top-15 rating on income from sales), 2017, mln. UAH

\begin{tabular}{|l|c|}
\hline Name of Enterprise & Revenues from sales of products, UAH million \\
\hline \multicolumn{1}{|c|}{1} & 2 \\
\hline Kernel & 2329,5 \\
\hline Nibulone & 1946,4 \\
\hline Myronivsky Hliboproduct & 1062,2 \\
\hline UkrLandFarming & 937,5 \\
\hline Vioil & 373,0 \\
\hline Astarta & 347,5 \\
\hline Allseeds Group & 294 \\
\hline Agroproperty & 293,1 \\
\hline T.B.Fruit & 219,1 \\
\hline Ukrprominvest Agr & 185,3 \\
\hline Prometheus & 150,3 \\
\hline Industrial Dairy Company & 140,4 \\
\hline Agromars & 136,5 \\
\hline Agrotrade & 131,5 \\
\hline Ukrainian agrarian investments & 123,3 \\
\hline
\end{tabular}

Source: Formed by the author's (Eurasian Development Bank) [21] 
Particular attention should be paid to the fact that the company's leaders achieved high results through a marketing mix formation, focusing on each element, applying the modern marketing concept, marketing strategies of internationalization, and effectively managing brands portfolio.

Consider the marketing complex characteristics, marketing strategy, brands portfolio of PJSC "Myronivsky Hliboproduct" (Chart 7 - 9) [22].

Chart 7. Characteristics of the marketing complex of PJSC "Myronivsky Hliboproduct" [22]

\begin{tabular}{|l|l|l|l|}
\hline $\begin{array}{l}\text { Commodity } \\
\text { specialization of } \\
\text { the enterprise }\end{array}$ & $\begin{array}{l}\text { Pricing } \\
\text { policy }\end{array}$ & Organization of sale & Promotion \\
\hline $\begin{array}{l}\text { «02 Meat and } \\
\text { edible offal / } \\
\text { poultry», } \\
\text { «07 Vegetables», } \\
\text { «10 Grain } \\
\text { Cultures» }\end{array}$ & $\begin{array}{l}\text { Purchase } \\
\text { prices are } \\
\text { defined on } \\
\text { the site }\end{array}$ & $\begin{array}{l}\text { Export of winter rape and wheat, } \\
\text { use of grain for own needs. } \\
\text { Sale of crop production, poultry } \\
\text { industry in domestic and } \\
\text { international markets. } \\
\text { Establishment of own production } \\
\text { of poultry meat processing in the } \\
\text { Netherlands. }\end{array}$ & $\begin{array}{l}\text { Participation in international } \\
\text { exhibitions, contests, branding of } \\
\text { brands Nasha Ryaba, Easily, } \\
\text { Bashchinsky, Myronivsky bakery - } \\
\text { on the domestic market, Qualiko - } \\
\text { promotion of frozen poultry } \\
\text { products in international markets. } \\
\text { https://www.mhp.com.ua }\end{array}$ \\
\hline
\end{tabular}

Source: Formed by the author for (Official site of PJSC "MHP") [22]

Chart 8. Characteristics of the marketing strategy of PJSC "Myronivsky Hliboproduct" [22]

\begin{tabular}{|c|c|c|c|}
\hline Marketing strategy & $\begin{array}{l}\text { Quality standards } \\
\text { compliance, } \\
\text { certification }\end{array}$ & Marketing innovations & Plans for the future \\
\hline \begin{tabular}{|l|} 
Construction of \\
modern enterprises. \\
Increasing the share \\
of domestic and \\
international markets. \\
Expansion of the \\
sales system.
\end{tabular} & $\begin{array}{l}\text { ISO } 9001 \text { - an } \\
\text { international } \\
\text { standard of quality, } \\
\text { ISO 22000, FSSC } \\
\text { International Food } \\
\text { Safety Standard. }\end{array}$ & $\begin{array}{l}\text { Restructuring of Eurobonds } \\
\text { for } 750 \text { milliard, } \\
\text { Exchange of assets with the } \\
\text { Russian company } \\
\text { "Agrokultura" } \\
\text { Development of own } \\
\text { technologies for providing } \\
\text { incubation eggs of own } \\
\text { production. }\end{array}$ & $\begin{array}{l}\text { To increase the land bank up to } \\
500000 \text { hectares } \\
\text { Expansion of sales markets and } \\
\text { increase of export volumes to } \\
\text { CIS, Middle East, and EU } \\
\text { markets. Increase of the land } \\
\text { bank up to } 50 \text { ths }\end{array}$ \\
\hline
\end{tabular}

Source: Formed by the author for (Official site of PJSC "MHP") [22]

Vertical integration provides PJSC "Myronivsky Hliboproduct" with a wide range of possibilities:

- self-sufficiency in crops: the use of own grain for the production of mixed fodders, enriched with protein, vitamins and minerals necessary for the development of chickens; - Unique sunflower seed protein production technology: PJSC "Myronivsky Hliboproduct" is the only producer of chicken in the world, which uses a special technology for the production of sunflower seeds. As a result of protein production, there are third-party products that are used in other industries and are marketed in the market: oil is exported, sunflower husk is used for littering in poultry houses and as fuel for obtaining steam energy at the feed mills of Myronivsky Hliboproduct PJSC;

- control of all stages of the production of chicken: from the best German producers, both parent farms of the Myronivsky Hliboproduct PJSC receive day-old chicks, which in poultry houses turn into a parent stock of broiler chickens. Eggs, obtained from 
parent poultry farms, are transported to incubators located in broiler chicken breeding farms. The incubation process lasts 21 days. Newly-born chickens are immediately vaccinated, after which they are transported to poultry houses of broiler poultry farms; - closed production cycle: agricultural holding enterprises of PJSC "Myronivsky Hliboproduct" for chicken production operate in a closed loop, which involves modern incubators, broiler chicken breeding zones, poultry meat processing complexes and mixed fodder plants. This structure allows you to control every production line, reduce the risk of infection and poultry diseases at one stage or another, to produce safe and high-quality products;

- possibility of utilization of waste products: a biogas station with capacity of $5 \mathrm{MW}$, which operates on chicken litter and poultry farms, works at the Oril-Leader poultry farm;

- A wide range of meat processing products: the meat processing segment is an important part of the vertical integration model. PJSC "Myronivsky Hliboproduct" produces a wide range of products from smoked chicken to semi-finished products. The chicken of its own production is the main raw material for meat processing and constitutes more than $50 \%$ of the product, the rest - pork and / or beef;

- Rapid delivery of products: PJSC "Myronivsky Hliboproduct" uses its own 450 refrigerated trucks, which control compliance with the correct temperature regime in the delivery process, which takes no more than 24 hours after the final stage of production;

- Clear sales structure: in Ukraine, Myronivsky Hliboproduct PJSC sells its products through supermarkets (40\%), franchising (40\%) and HoReCa (20\%), maintaining a balance between supermarket sales and franchising. Since 2008, Myronivsky Hliboproduct PJSC actively develops poultry meat exports, now having more than 80 countries in its export portfolio;

- A franchised network is developed: around 40\% of sales are through 2200 branded retail outlets of PJSC "Myronivsky Hliboproduct" throughout Ukraine, which operate according to a single standard. The established partnerships with supermarket chains allow the Myronivsky Hliboproduct PJSC to maintain an extensive customer base.

The analysis of foreign economic activity of PJSC "Myronivsky Hliboproduct" allows us to conclude that the company shows the highest export performance indicators and has established poultry sales channels in 80 markets of the world, in particular:

- in 23 markets of EU countries: Belgium, Bulgaria, Great Britain, Gibraltar, Estonia, Ireland, Italy, Canary Islands, Cyprus, Lithuania, Macedonia, Netherlands, Germany, Poland, Romania, Slovakia, Slovenia, Hungary, France, Croatia, Czech Republic, Montenegro, Switzerland;

- in 11 markets in the Middle East: Afghanistan, Bahrain, Yemen, Iraq, Jordan, Kuwait, Lebanon, the United Arab Emirates, Oman, Saudi Arabia, Turkey;

- in 30 markets in Africa: Angola, Benin, Vietnam, Gabon, Gambia, Ghana, Guinea, Hong Kong, the Democratic Republic of the Congo, Djibouti, Equatorial Guinea, Ethiopia, Egypt, Zanzibar, Cape Verde, Cameroon, Kenya, Ivory Coast, Liberia, Libya, Mauritania, Malaysia, Maldives, Morocco, Mozambique, the Republic of Congo, Seychelles, Sierra Leone, Togo, Central African Republic;

- 9 markets of the CIS countries: Azerbaijan, Armenia, Georgia, Kazakhstan, Kyrgyzstan, Moldova, Tajikistan, Turkmenistan, Uzbekistan. 
- in 9 markets of the United Nations: the Democratic Republic of the Congo, Israel, Cyprus, Lebanon, Mali, Southern Sudan, Somalia, Sudan.

In order to expand its activities, in 2011, the company created its own trademark Qualiko, a brand of frozen poultry products presently present in the CIS, the EU, the Middle East, Asia and Africa, and also exported to 80 countries of the world. TM Qualiho products are ecological, natural, useful and fresh, because they are made of natural raw materials with extremely strict quality control, in compliance with the high world standards.

11 distribution centers and own car fleet of refrigerated cars allow to deliver refrigerated and frozen products to customers as soon as possible. The assortment of the packaged products of the brand is represented by frozen poultry meat: whole carcass and chickenbroiler pieces.

In 2015, exports of PJSC "Myronivsky Hliboproduct" to the EU countries grew by 65\%. Compared to last year, exports amounted to 27285 tons to 17 countries of Europe (National Agroportal "Latifundist"). The export of chilled chicken started to this market. PJSC "Myronivsky Hliboproduct" continues to implement the strategy of diversification of markets and explore new markets for doing business in Asia, the Middle East and Africa, increasing the volume of exports of poultry to these regions. In 2015, MHP also received permission to export its products to Saudi Arabia (agrarian news agency Agravery, Official site of MHP PJSC) [18, 22].

During the second quarter of 2016, Myronivsky Hliboproduct exported poultry meat at 54.4 thousand tons, which is $36 \%$ more compared to the second quarter of 2015 . In the first half of 2016, poultry meat exports increased by 31\%, compared with with the first half of 2015, and amounted to 86.4 thousand tons (agrarian news agency Agravery, Official site of PJSC "MHP") [18, 22].

Besides, the volume of poultry meat production in the company in the second quarter of 2016 increased by $9 \%$ to 149.9 thousand tons (second quarter of 2015 - 138.1 thousand tons) and in the first half of 2016 increased by $10 \%$ to 305, 5 thousand tons (first halfyear 2015 - 278.4 thousand tons) (agrarian news agency "Agravery", Official site of PJSC "MHP") [18, 22].

As a result of the overall increase in poultry production in the second quarter of 2016, the sales of chicken to external consumers increased to 148.9 thousand tons, which is $4 \%$ higher than in the second quarter of 2015 and 26\% higher than in the first quarter. 2016, mainly due to the growth of export sales (Agravery agrarian news agency, Official site of MHP PJSC) [18, 22].

PJSC "Myronivsky Hliboproduct" in 2017 increased export sales by 10\%, and the volume of poultry meat production - by 2-3\% compared with 2016 . Increase exports by 40\% to 190 thousand tons (Official site of PJSC "MHP") [22].

In 2014 PJSC "Myronivsky Hliboproduct" held an asset exchange with Agrokultura. In addition, MHP lost its Russian assets (40 thousand hectares) in exchange for land with an area of 60 thousand hectares. in the Lviv, Ternopil and Ivano-Frankivsk regions, the Russian side initiated the exchange (the 5 largest agricultural companies in Ukraine by the size of the land bank) [20].

Following the compilation of a list of possible international markets (countries) and the study of the possibility of implementing the internationalization strategy by the Ukrainian 
meat producer of PJSC Myronivsky Hliboproduct, the markets for which poultry meat sales are available, in particular the following markets: Angola, Benin, B ' Ethiopia, Gabon, Gambia, Ghana, Guinea, Hong Kong, the Democratic Republic of the Congo, Djibouti, Equatorial Guinea, Ethiopia, Egypt, Zanzibar, Cape Verde, Cameroon, Kenya, Côte d'Ivoire, Liberia, Libya, Mauritania, Malaysia, Maldives , Morocco, Mozambique, R the Republic of Congo, the Seychelles, Sierra Leone, the Central African Republic, Afghanistan, Bahrain, Yemen, Iraq, Jordan, Kuwait, Lebanon, the United Arab Emirates, Oman, Saudi Arabia, Turkey, Belgium, Bulgaria, United Kingdom, Gibraltar, Estonia, Ireland, Italy, Canary Islands, Cyprus, Lithuania, Macedonia, Netherlands, Germany, Poland, Romania, Slovakia, Slovenia, Hungary, France, Croatia, Czech Republic, Montenegro, Switzerland, the Democratic Republic of the Congo, United Nations, UN, Cyprus, United Nations, Lebanon UN, Mali UN, P indaytime UN Sudan, Somalia, the UN, the UN Sudan, Azerbaijan, Georgia, Kazakhstan, Kyrgyzstan, Moldova, Tajikistan, Turkmenistan, Uzbekistan.

The preliminary selection of markets, the exclusion from the list of the least attractive markets allowed PJSC "Myronivsky Hliboproduct" to segment more than 200 international markets into segments - "Most attractive", "least attractive", "Need detailed study".

Considering the segment "Most attractive", the largest leading international markets importers were investigated, where PJSC "Myronivsky Hliboproduct" sells the product group "0207 Poultry" (Chart 9-10).

Chart 9. Characteristics of the leading import-dependent international markets according to the product group "0207 Poultry Meat", which is engaged in business activities of PJSC "Myronivsky Hliboproduct" [23]

\begin{tabular}{|l|c|c|c|c|c|c|}
\hline Exporters & $\begin{array}{c}\text { Volume of } \\
\text { imports of } \\
\text { poultry } \\
\text { meat, 2017, } \\
\text { thsd }\end{array}$ & $\begin{array}{c}\text { Balance of } \\
\text { trade } \\
\text { balance, } \\
2017, \\
\text { thousand } \\
\text { dollars }\end{array}$ & $\begin{array}{c}\text { Specific weight } \\
\text { of poultry meat } \\
\text { from Ukraine in } \\
\text { the total volume } \\
\text { of imports of } \\
\text { Ukraine, } \%\end{array}$ & $\begin{array}{c}\text { Quantity of } \\
\text { imports of } \\
\text { poultry meat, } \\
2017 \text { tons }\end{array}$ & $\begin{array}{c}\text { Distance } \\
\text { between } \\
\text { partner } \\
\text { countries, } \\
\mathrm{km}\end{array}$ & $\begin{array}{c}\text { Concentration } \\
\text { of all importing } \\
\text { countries of } \\
\text { partner } \\
\text { countries }\end{array}$ \\
\hline World & 48510 & 341522 & 100 & 118310 & & 0,1 \\
\hline Poland & 32468 & -29815 & 66,9 & 81273 & 1422 & 0,12 \\
\hline Germany & 6271 & 15395 & 12,9 & 14567 & +856 & 0,09 \\
\hline Hungary & 2502 & -2446 & 5,2 & 6045 & 1393 & 0,09 \\
\hline France & 1743 & -1062 & 3,6 & 3727 & 2373 & 0,11 \\
\hline Great Britain & 1543 & -1000 & 3,2 & 3926 & 2590 & 0,15 \\
\hline The Netherlands & 1332 & 76951 & 2,7 & 3286 & 1319 & 0,15 \\
\hline Lithuania & 486 & -350 & 1 & 1117 & 1383 & 0,21 \\
\hline Belgium & 266 & -180 & 0,5 & 693 & 1286 & 0,18 \\
\hline Italy & 161 & 121 & 0,3 & 318 & 1582 & 0,63 \\
\hline Yemen & 139 & -139 & 0,3 & 99 & 3390 & 0,42 \\
\hline Czech Republic & 45 & 946 & 0,1 & 105 & 338 & 0,44 \\
\hline Georgia & 29 & 9636 & 0,1 & 19 & 1738 & \\
\hline
\end{tabular}

Source: Formed by the author for (Trade Statistics for the Development of International Business) [23] 
Chart 10. Dynamics of import volumes of the commodity group "0207 Poultry meat" of the markets - the leading Ukrainian importers, in which they carry out business activities of PJSC "Myronivsky Hliboproduct" [23]

\begin{tabular}{|l|c|c|c|c|c|}
\hline Exporters & $\begin{array}{c}\text { Volume of } \\
\text { imports of } \\
\text { poultry meat, } \\
2013, \text { thsd }\end{array}$ & $\begin{array}{c}\text { Volume of } \\
\text { imports of } \\
\text { poultry meat, } \\
2014, \text { thsd }\end{array}$ & $\begin{array}{c}\text { Volume of } \\
\text { imports of } \\
\text { poultry meat, } \\
2015, \text { thsd }\end{array}$ & $\begin{array}{c}\text { Volume of } \\
\text { import of } \\
\text { poultry meat, } \\
2016, \text { thsd }\end{array}$ & $\begin{array}{c}\text { Volume of } \\
\text { import of } \\
\text { poultry meat, } \\
\text { 2017, thsd }\end{array}$ \\
\hline World & 101534 & 57635 & 37377 & 34281 & 48510 \\
\hline Poland & 8045 & 15412 & 20326 & 19784 & 32468 \\
\hline Germany & 30158 & 15568 & 9564 & 7174 & 6271 \\
\hline Hungary & 14073 & 5283 & 904 & 966 & 2502 \\
\hline France & 3674 & 2671 & 868 & 981 & 1743 \\
\hline Gerat Britain & 10187 & 4571 & 2061 & 1511 & 1543 \\
\hline The Netherlands & 5657 & 2871 & 949 & 1302 & 1332 \\
\hline Lithuania & 0 & 0 & 49 & 171 & 486 \\
\hline Belgium & 1539 & 975 & 227 & 330 & 266 \\
\hline Italy & 5991 & 2407 & 558 & 787 & 161 \\
\hline Yemen & 0 & 0 & 0 & 0 & 139 \\
\hline Czech Republic & 0 & 0 & 0 & 37 & 45 \\
\hline Georgia & 0 & 23 & 0 & 0 & 29 \\
\hline
\end{tabular}

Source: Formed by the author for (Trade Statistics for the Development of International Business) [23]

As can be seen from Chart 9, 10 - all markets for the sale of the commodity group "0207 Poultry meat" for PJSC "Myronivsky Hliboproduct" during the last five years have been increasing the volume of imports, except for the market of Belgium, Italy. Markets in Yemen, the Czech Republic, and Georgia show positive dynamics in 2017. The rest of the markets in which Myronivsky Hliboproduct PJSC operates are import-dependent from the commodity group "0207 Poultry Meat", however, they do not fall into the Top 10 Importers.

Considering the segment "The least attractive" all markets that self -provide the domestic market by the product was rejected. That is, the markets in which the agro-industrial sector has been developed, in particular animal husbandry. The countries of this segment are world leaders exporters of the commodity group "0207 Poultry" (Chart 11).

Chart 11. Characteristics of the leading world exporters for the product group "0207 Poultry", 2017. - Segment "The Lower Leading Markets" [23]

\begin{tabular}{|l|c|c|c|c|c|}
\hline Exporters & $\begin{array}{c}\text { Sales volume of } \\
\text { poultry meat, } \\
2017, \\
\text { thousand dollars }\end{array}$ & $\begin{array}{c}\text { Balance of } \\
\text { trade balance, } \\
\text { thsd. }\end{array}$ & $\begin{array}{c}\text { Number of } \\
\text { exported } \\
\text { goods, 2017, } \\
\text { Tone }\end{array}$ & $\begin{array}{c}\text { Specific weight of } \\
\text { poultry sales meat } \\
\text { in the total world } \\
\text { sales volume, } \%\end{array}$ & $\begin{array}{c}\text { Average distance } \\
\text { between partner } \\
\text { markets, km }\end{array}$ \\
\hline 1 & 2 & 3 & 4 & 5 & 6 \\
\hline World & 25833581 & 1662895 & 0 & 100 & 5448 \\
\hline Brazil & 6577583 & 6569066 & 4020022 & $+25,5$ & 12633 \\
\hline USA & 3633302 & 3391494 & 3430718 & 14,1 & 7003 \\
\hline The Netherlands & 2576746 & 1656579 & 1464078 & 10 & 1319 \\
\hline Poland & 2107386 & 2022990 & 1079824 & 8,2 & 1422 \\
\hline Hong Kong, China & 1145008 & -314430 & 659753 & 4,4 & +842 \\
\hline Germany & 1018703 & -682406 & 455641 & 3,9 & +856 \\
\hline Belgium & 993552 & 478277 & 615901 & 3,8 & 1286 \\
\hline
\end{tabular}




\begin{tabular}{|c|c|c|c|c|c|}
\hline Exporters & \begin{tabular}{|c|}
$\begin{array}{c}\text { Sales volume of } \\
\text { poultry meat, } \\
2017 \\
\text { thousand dollars }\end{array}$ \\
\end{tabular} & $\begin{array}{c}\text { Balance of } \\
\text { trade balance, } \\
\text { thsd. }\end{array}$ & $\begin{array}{c}\text { Number of } \\
\text { exported } \\
\text { goods, 2017, } \\
\text { Tone }\end{array}$ & $\begin{array}{c}\text { Specific weight of } \\
\text { poultry sales meat } \\
\text { in the total world } \\
\text { sales volume, } \%\end{array}$ & $\begin{array}{c}\text { Average distance } \\
\text { between partner } \\
\text { markets, } \mathrm{km}\end{array}$ \\
\hline 1 & 2 & 3 & 4 & 5 & 6 \\
\hline France & 956962 & -252133 & 419041 & 3,7 & 2373 \\
\hline Thailand & 610934 & 609570 & 229726 & 2,4 & 3610 \\
\hline China & 557315 & -474390 & 240488 & 2,2 & 1768 \\
\hline Hungary & 535832 & 415709 & 0 & 2,1 & 1393 \\
\hline Turkish & 526551 & 524476 & 412552 & 2 & 2438 \\
\hline Ukraine & 390032 & 341522 & 271521 & 1,5 & 2467 \\
\hline Italy & 374217 & 213742 & 165412 & 1.4 & 1582 \\
\hline Great Britain & 361970 & -1154247 & 344869 & 1.4 & 2590 \\
\hline Spain & 349582 & -53995 & 211474 & 1.4 & +1985 \\
\hline \begin{tabular}{|l|} 
Argentina \\
\end{tabular} & 285244 & 281139 & 204099 & 1,1 & 13020 \\
\hline $\begin{array}{l}\text { Chile } \\
\end{array}$ & 274183 & 59446 & 95934 & 1,1 & 10093 \\
\hline Belorussia & 224302 & 210909 & 150420 & 0.9 & 1171 \\
\hline Canada & 203203 & -154278 & 128437 & 0.8 & 5259 \\
\hline Austria & 198338 & -127893 & 61276 & 0.8 & 497 \\
\hline Bulgaria & 181769 & 60584 & 44036 & 0.7 & 1406 \\
\hline Russian Federation & 172903 & -187029 & 163281 & 0.7 & 2573 \\
\hline Denmark & 153841 & -20809 & 81652 & 0.6 & 3247 \\
\hline Saudi Arabia & 138572 & -1063120 & 35780 & 0,5 & 1044 \\
\hline Romania & 129894 & -60885 & 59406 & 0,5 & 1536 \\
\hline Ireland & 114691 & -195596 & 78363 & 0,4 & +3800 \\
\hline \begin{tabular}{|l} 
Lithuania \\
\end{tabular} & 108426 & 46635 & 54507 & 0,4 & 1383 \\
\hline South Africa & 98497 & -382212 & 66224 & 0,4 & 980 \\
\hline Czech Republic & 78247 & -204382 & 37901 & 0,3 & 338 \\
\hline Portugal & 64513 & -100194 & 41461 & 0.2 & 1802 \\
\hline Australia & 54792 & 54629 & 41829 & 0.2 & 5358 \\
\hline Slovenia & 48824 & 3485 & 20088 & 0.2 & 422 \\
\hline Slovakia & 47394 & -69424 & 21563 & 0.2 & 359 \\
\hline $\begin{array}{l}\text { United Arab } \\
\text { Emirates }\end{array}$ & 44120 & -725699 & 24307 & 0.2 & 1746 \\
\hline New Zealand & 40636 & 39794 & 16659 & 0.2 & 4273 \\
\hline \begin{tabular}{|l|} 
Sweden \\
\end{tabular} & 37893 & -156199 & 74410 & 0,1 & 1681 \\
\hline $\begin{array}{l}\text { Iran, Islamic } \\
\text { Republic }\end{array}$ & 35558 & 35558 & 45492 & 0,1 & 4281 \\
\hline Oman & 33460 & -115249 & 10509 & 0,1 & 481 \\
\hline \begin{tabular}{|l|} 
Latvia \\
\end{tabular} & 28827 & -17607 & 17078 & 0,1 & 512 \\
\hline Greece & 28075 & -126142 & 30724 & 0,1 & +1210 \\
\hline Singapore & 25287 & -210563 & 18138 & 0,1 & 1444 \\
\hline Benin & 22632 & $\begin{array}{l}-77788 \\
\end{array}$ & 15467 & 0,1 & 290 \\
\hline \begin{tabular}{|l|} 
Jordan \\
\end{tabular} & 19472 & -72416 & 7831 & 0,1 & 1433 \\
\hline Croatia & 18733 & -30650 & 7760 & 0,1 & 480 \\
\hline Japan & 17619 & -1381888 & 10004 & 0,1 & 3430 \\
\hline Malaysia & 13846 & -130986 & 10717 & 0,1 & +966 \\
\hline Namibia & 11854 & -19524 & 11823 & 0 & +1901 \\
\hline Estonia & 11656 & -22566 & 6566 & 0 & 1136 \\
\hline
\end{tabular}

Source: Formed by the author for (Trade Statistics for the Development of International Business) [23] 
Considering the segment "Need for a detailed study", markets were identified which, by all indicators, are import-dependent from the commodity group "0207 Poultry Meat". In determining the target segments and assessing the availability of opportunities for agrarian enterprises on them, the results of the study were formed in the chart 12 .

According to the conducted segmentation of the international markets, it was determined that the markets of Portugal, Slovakia, Latvia, Finland, Spain, Denmark are potentially available for sale to them by the product group "0207 Poultry meat" by the company "Myronivsky Hliboproduct" PJSC as being in existence demand for poultry meat - that is, they are import-dependent for this commodity group.

Chart 12. Dynamics commodity group import "0207 Poultry" on potential sales markets for PJSC "Myronivsky Hliboproduct" [23]

\begin{tabular}{|l|c|c|c|c|c|}
\hline & \multicolumn{5}{|c|}{ Volume of poultry meat imports from Ukraine, thsd } \\
\hline Exporters & 2013 & 2014 & 2015 & 2016 & 2017 \\
\hline World & 101534 & 57635 & 37377 & 34281 & 48510 \\
\hline Spain & 1709 & 1342 & +1040 & 259 & 422 \\
\hline Denmark & 64 & 331 & 353 & 55 & 641 \\
\hline Lithuania & 0 & 0 & 0 & 0 & 114 \\
\hline Finland & 0 & 0 & 0 & 73 & 316 \\
\hline China & 124 & 85 & 37 & 0 & 0 \\
\hline Slovakia & 37 & 0 & 0 & 0 & 0 \\
\hline Armenia & 0 & 0 & 0 & 20 & 0 \\
\hline Belorussia & 0 & 0 & 0 & 196 & 0 \\
\hline Estonia & 0 & 0 & 26 & 0 & 0 \\
\hline Jordan & 0 & 0 & 0 & 25 & 0 \\
\hline Portugal & 0 & 0 & 0 & 0 & 10 \\
\hline Austria & 0 & 0 & 0 & 0 & 0 \\
\hline Malta & 0 & 0 & 0 & 0 & 0 \\
\hline Greece & 0 & 0 & 0 & 0 & 0 \\
\hline
\end{tabular}

Source: Formed by the author for (Trade Statistics for the Development of International Business) [23]

There is a low concentration of competition and the admissible distance of the partner market in these markets. The markets of Jordan, Estonia, Armenia can become new markets for PJSC "Myronivsky Hliboproduct" by the commodity group "0207 Poultry" on the basis of "Distance between Partner Countries". Markets in Belarus, Austria, Malta, Greece, and China are potential new markets for PJSC "Myronivsky Hliboproduct" as markets where the low "Concentration of All Countries of Importing Partner Countries" is low.

When choosing methods for assessing the attractiveness of international markets, it is important that, in the context of implementing the internationalization strategy, Ukrainian meat producers can not be guided by universal solutions, because this process requires creativity aimed at satisfying the requirements of a particular consumer in a particular market and period of time. Identify the most typical forms of implementing marketing strategies by Ukrainian meat producers in the markets of Portugal, Slovakia, Latvia, Finland, Spain, Denmark, Jordan, Estonia, Armenia, Byelorussia, Austria, Malta, Greece, China according to the indicators of the attractiveness of their business 
environment, which it is important to take into account for further development and implementation of the strategy of internationalization by Ukrainian meat producers (Chart13).

Chart 13. Estimation of the business environment attractiveness of new international markets for Ukrainian meat producers by the product group "0207 Poultry", 2016-2018.

\begin{tabular}{|c|c|c|c|c|c|c|c|c|c|c|c|c|c|c|c|}
\hline $\begin{array}{l}\text { Factor / } \\
\text { foreign market }\end{array}$ & $\overbrace{}^{2}$ & 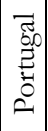 & 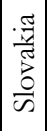 & 苞 & 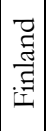 & $\begin{array}{l}\text { ज्ञ } \\
\text { صै }\end{array}$ & 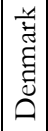 & 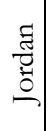 & 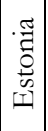 & 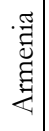 & 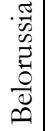 & 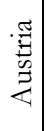 & $\frac{\pi}{\pi}$ & $\left|\begin{array}{l}\tilde{U} \\
\tilde{J} \\
\tilde{U}\end{array}\right|$ & 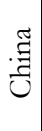 \\
\hline 1 & 2 & 3 & 4 & 5 & 6 & 7 & 8 & 9 & 10 & 11 & 12 & 13 & 14 & 15 & 16 \\
\hline \multicolumn{16}{|c|}{ Main economic indicators } \\
\hline \multirow{2}{*}{$\begin{array}{l}\text { Economic } \\
\text { growth, } \%\end{array}$} & 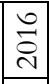 & 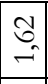 & \begin{tabular}{|l|} 
\\
$\mathrm{m}^{2}$ \\
$\mathrm{~m}^{2}$
\end{tabular} & $\overrightarrow{\hat{n}_{1}}$ & $\underset{|c|}{+i}$ & $\begin{array}{l}\hat{N} \\
\text { n̂. }\end{array}$ & $\stackrel{2}{\curvearrowleft}$ & $\begin{array}{l}0 \\
\text { i } \\
\end{array}$ & \begin{tabular}{|l|} 
\\
0 \\
$i$ \\
\end{tabular} & r. & \begin{tabular}{|l|l|}
$\hat{n}$ \\
$\hat{n}$ \\
$\hat{1}$ \\
\end{tabular} & $\stackrel{2}{\rightarrow}$ & \begin{tabular}{|l|}
\multirow{2}{n}{} \\
$n^{n}$ \\
\end{tabular} & 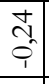 & $\hat{\sigma}$ \\
\hline & $\overrightarrow{\tilde{c}}$ & $\left|\begin{array}{c}\infty \\
0 \\
i \\
i\end{array}\right|$ & $\begin{array}{c}0 \\
i^{n}\end{array}$ & $\begin{array}{l}\ln \\
\stackrel{n}{f}\end{array}$ & $\begin{array}{l}3 \\
\tilde{6} \\
i\end{array}$ & $\stackrel{n}{0}$ & $\stackrel{0}{\sim}$ & $\stackrel{\hat{a}}{\rightarrow}$ & $\mid \begin{array}{l}\infty \\
\infty \\
+ \\
+\end{array}$ & $\begin{array}{l}n \\
n\end{array}$ & 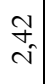 & $\begin{array}{c}t \\
\dot{m}\end{array}$ & 刭 & $\stackrel{\substack{n \\
\rightarrow}}{\rightarrow}$ & ̊. \\
\hline \multirow{2}{*}{$\begin{array}{l}\text { GDP at current prices, } \\
\text { billion dollars }\end{array}$} & $\begin{array}{l}0 \\
\overrightarrow{\tilde{\sigma}} \\
\end{array}$ & 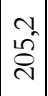 & $\stackrel{\hat{a}}{\infty}$ & $\begin{array}{l}\hat{n} \\
\hat{n}\end{array}$ & \begin{tabular}{|l|}
$\infty$ \\
0 \\
$\infty$ \\
$\infty$ \\
$\infty$
\end{tabular} & 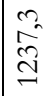 & $\begin{array}{l}0 \\
0 \\
\delta \\
0 \\
0\end{array}$ & $\mid \begin{array}{l}10 \\
0 \\
\infty \\
n \\
n\end{array}$ & $\left|\begin{array}{l}\vec{w} \\
\hat{\sim} \\
\hat{v}\end{array}\right|$ & $\begin{array}{l}2 n \\
2 \\
0 \\
0 \\
0\end{array}$ & $\mid \begin{array}{l}n \\
\stackrel{2}{f} \\
f\end{array}$ & $\begin{array}{l}\infty \\
\stackrel{n}{m}\end{array}$ & 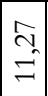 & 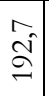 & $\begin{array}{l}\hat{\Omega} \\
\hat{\Omega} \\
\varrho \\
\Xi\end{array}$ \\
\hline & $\overrightarrow{\tilde{\sigma}}$ & $\left|\begin{array}{c}0 \\
\vec{v} \\
\vec{v}\end{array}\right|$ & $\begin{array}{c}\hat{N} \\
2 \\
2\end{array}$ & \begin{tabular}{l}
0 \\
\multirow{2}{*}{} \\
$\hat{n}$ \\
$\tilde{n}$
\end{tabular} & $\left|\begin{array}{c}\infty \\
\stackrel{n}{\sim} \\
\stackrel{n}{\sim}\end{array}\right|$ & $\begin{array}{l}\stackrel{n}{\approx} \\
\stackrel{n}{=}\end{array}$ & $\begin{array}{l}a \\
\stackrel{\tilde{N}}{\tilde{m}}\end{array}$ & $\mid \begin{array}{l}\hat{\sigma} \\
\hat{f} \\
\mid\end{array}$ & 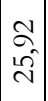 & $\stackrel{+}{\stackrel{+}{2}}=$ & $\begin{array}{l}0 \\
y_{n} \\
\dot{f} \\
n\end{array}$ & $\begin{array}{l}0 \\
\stackrel{0}{0} \\
\vec{f}\end{array}$ & 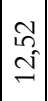 & 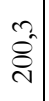 & 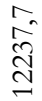 \\
\hline \multirow{2}{*}{$\begin{array}{l}\text { GDP per capita by purchasing power parity, } \\
\text { thousand dollars / person }\end{array}$} & $\stackrel{0}{\stackrel{0}{0}}$ & $\begin{array}{c}\hat{-} \\
\hat{-} \\
\infty \\
2 \\
-\end{array}$ & 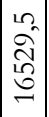 & 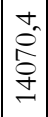 & 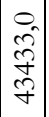 & 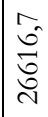 & $\begin{array}{l}\hat{n} \\
\infty \\
i n \\
\hat{n} \\
\hat{n}\end{array}$ & 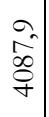 & $\begin{array}{l}\infty \\
\infty \\
0 \\
\stackrel{2}{2} \\
I \\
-\end{array}$ & 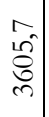 & 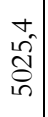 & $\begin{array}{l}\stackrel{\sigma}{\vec{n}} \\
\stackrel{\tilde{f}}{f}\end{array}$ & 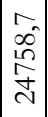 & 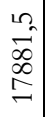 & 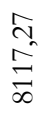 \\
\hline & $\overrightarrow{\hat{D}}$ & 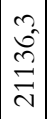 & 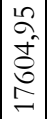 & 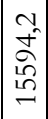 & $\begin{array}{c}m \\
\hat{2} \\
\hat{2} \\
\frac{1}{\sigma}\end{array}$ & \begin{tabular}{|l}
$\infty$ \\
$\infty$ \\
$\stackrel{\infty}{n}$ \\
$\stackrel{\infty}{\infty}$ \\
त)
\end{tabular} & $\begin{array}{l}\vec{n} \\
\tilde{n} \\
\hat{\Omega} \\
\tilde{\delta} \\
\stackrel{n}{n}\end{array}$ & 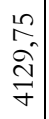 & 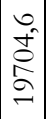 & 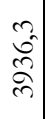 & $\begin{array}{l}n_{0} \\
\hat{N} \\
\hat{N}\end{array}$ & 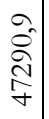 & 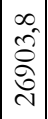 & 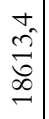 & $\begin{array}{l}\hat{\sigma} \\
\text { ஸे } \\
\infty \\
\infty\end{array}$ \\
\hline \multirow{2}{*}{ Inflation rate (by consumer price index) } & 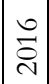 & $\stackrel{-}{\rightarrow}$ & $\begin{array}{l}10 \\
0 \\
0\end{array}$ & $\overrightarrow{0}$ & $\dot{t}_{0}$ & $\begin{array}{l}2 \\
0 \\
0\end{array}$ & $\stackrel{2}{0}^{2}$ & $\begin{array}{l}\infty \\
0 \\
1\end{array} \mid$ & $\overrightarrow{0}$ & $\stackrel{\sigma_{n}}{\tau_{1}}$ & $\stackrel{\infty}{=}$ & $\stackrel{0}{\rightarrow}$ & $\ddot{0}^{0}$ & $\left|\begin{array}{l}\infty \\
0 \\
0 \\
1\end{array}\right|$ & $\stackrel{0}{i}$ \\
\hline & \begin{tabular}{|l|l|}
\multirow{2}{*}{} \\
\end{tabular} & $\stackrel{{ }^{\prime}}{\rightarrow}$ & $\stackrel{2}{\sim}$ & $\hat{\vec{v}}$ & $\left|\begin{array}{l}\infty \\
0\end{array}\right|$ & in & $\Rightarrow$ & $\stackrel{m}{m}$ & $\begin{array}{c}\dot{\sigma}_{n} \\
\text { | }\end{array}$ & $\stackrel{0}{\rightarrow}$ & $\begin{array}{l}0 \\
0\end{array} \mid$ & $\overrightarrow{\mathrm{i}}$ & $\stackrel{\sigma_{\infty}}{-}$ & $\Rightarrow$ & $\stackrel{0}{-}$ \\
\hline \multirow{2}{*}{ Household consumption, $\%$} & 它 & 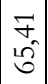 & 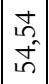 & $\frac{0}{0}$ & $\left|\begin{array}{c}\infty \\
i n \\
i n \\
\operatorname{in}\end{array}\right|$ & $\begin{array}{l}\text { to } \\
\text { in } \\
\text { in }\end{array}$ & 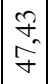 & $\begin{array}{c}\vec{\sigma} \\
\infty \\
\infty\end{array} \mid$ & $\mid \begin{array}{c}\hat{A} \\
\text { in } \\
\text { in }\end{array}$ & $\stackrel{m}{\stackrel{2}{r}}$ & $\begin{array}{l}\vec{n} \\
\dot{i n}\end{array}$ & $\begin{array}{c}\overrightarrow{\hat{n}} \\
\text { กิ }\end{array}$ & $\underset{f}{ \pm}$ & $\begin{array}{l}\infty \\
\infty \\
0 \\
0\end{array} \mid$ & 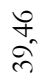 \\
\hline & $\stackrel{\sim}{\vec{\sigma}}$ & $\mid \begin{array}{c}1 \\
\hat{n}_{0} \\
\hat{0}\end{array}$ & $\stackrel{\sim}{\stackrel{n}{n}}$ & $\frac{N}{\tilde{\sigma}}$ & $\begin{array}{l}\hat{2} \\
i \tilde{n} \\
\dot{1}\end{array}$ & $\begin{array}{l}m \\
\stackrel{2}{2} \\
\text { in }\end{array}$ & $\begin{array}{l}\circ \\
\stackrel{2}{6} \\
+\end{array}$ & $\mid \begin{array}{l}0 \\
\stackrel{-}{6} \\
\infty\end{array}$ & 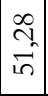 & $\begin{array}{l}\infty \\
\stackrel{2}{2} \\
\stackrel{1}{1}\end{array}$ & \begin{tabular}{l}
3 \\
$\infty$ \\
\multirow{1}{*}{} \\
in
\end{tabular} & $\begin{array}{c}\stackrel{N}{\sim} \\
\text { ก } \\
\text { ñ }\end{array}$ & $\mid \begin{array}{c}0 \\
\stackrel{f}{f}\end{array}$ & $\begin{array}{c}\hat{\sigma} \\
\hat{\sigma}\end{array}$ & $\begin{array}{l}\hat{2} \\
\infty \\
\curvearrowright\end{array}$ \\
\hline \multirow{2}{*}{ Savings, $\%$ of GDP } & 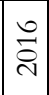 & \begin{tabular}{|c|} 
\\
$\sigma_{n}$ \\
$\hat{n}^{\prime}$ \\
\end{tabular} & $\begin{array}{l}\infty \\
\hat{\Omega} \\
\hat{v}\end{array}$ & $\begin{array}{l}\circ \\
\stackrel{2}{0} \\
\hat{\sim}\end{array}$ & \begin{tabular}{|l|} 
\\
$\hat{f}$ \\
$\hat{\sigma}$ \\
$\hat{v}$ \\
\end{tabular} & $\begin{array}{l}\tilde{f} \\
\tilde{v}\end{array}$ & 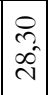 & 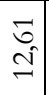 & 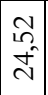 & $\begin{array}{l}\mathcal{V} \\
\sigma^{0} \\
\rightarrow\end{array}$ & $\begin{array}{l}\Omega \\
\hat{n} \\
0 \\
\sim \\
\sim\end{array}$ & 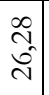 & $\begin{array}{l}\tilde{\hat{n}} \\
\hat{n}\end{array}$ & \begin{tabular}{|l|} 
\\
0 \\
0 \\
$0^{\prime}$
\end{tabular} & $\begin{array}{l}\infty \\
\infty \\
i f\end{array}$ \\
\hline & $\overrightarrow{\tilde{s}}$ & $\begin{array}{c}\vec{n} \\
\sigma^{-}\end{array}$ & $\begin{array}{l}\hat{w} \\
\hat{v} \\
\hat{v}\end{array}$ & $\begin{array}{l}\hat{6} \\
\hat{i}\end{array}$ & $\begin{array}{l}\tilde{b} \\
\hat{i}\end{array} \mid$ & $\mid \begin{array}{l}\hat{\alpha} \\
\infty \\
\tilde{d}\end{array}$ & 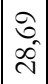 & 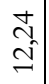 & $\left|\begin{array}{c}n \\
0 \\
\hat{n}\end{array}\right|$ & $\begin{array}{c}\stackrel{1}{-0} \\
\infty^{0}\end{array}$ & $\left|\begin{array}{c}\vec{\sigma} \\
\infty \\
i \\
\sim\end{array}\right|$ & $\begin{array}{l}\vec{\infty} \\
\hat{v}\end{array}$ & $\begin{array}{c}n \\
0 \\
\tilde{n} \\
n\end{array}$ & $\begin{array}{c}n \\
\tilde{2} \\
0 \\
-\end{array}$ & $\begin{array}{l}\vec{\sigma} \\
\sigma \\
\sigma\end{array}$ \\
\hline \multicolumn{16}{|c|}{ International trade conditions } \\
\hline \multirow{2}{*}{ Terms of trade, $\%$} & 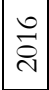 & $\mid \begin{array}{c}n \\
i n \\
0 \\
\Omega\end{array}$ & $\left|\begin{array}{c}\sigma \\
\infty \\
\hat{\sigma}^{\prime}\end{array}\right|$ & $\hat{\sigma}_{\mathscr{\sigma}}$ & $\begin{array}{c}\dot{a}_{1} \\
\hat{\sigma}\end{array}$ & 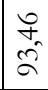 & $\begin{array}{l}\sigma \\
\hat{\sigma} \\
\widehat{\sigma}\end{array}$ & $\frac{\partial}{r}$ & $\begin{array}{c}\hat{\alpha} \\
\stackrel{2}{\alpha}\end{array}$ & 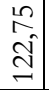 & $\begin{array}{c}0 \\
\hat{a}\end{array}$ & $\begin{array}{l}0 \\
0 \\
\infty \\
\infty \\
\infty\end{array}$ & 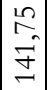 & $\begin{array}{l}1 n \\
\approx \\
\infty \\
\infty\end{array}$ & $\begin{array}{l}\tilde{n} \\
\tilde{\sigma} \\
0\end{array}$ \\
\hline & $\overrightarrow{\tilde{s}}$ & $\begin{array}{c}\vec{f} \\
\stackrel{2}{\Omega}\end{array}$ & $\begin{array}{l}\vec{n} \\
\hat{n} \\
\Omega\end{array}$ & $\mid \begin{array}{l}0 \\
0 \\
2 \\
0 \\
-1\end{array}$ & 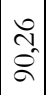 & $\mid \begin{array}{l}\infty \\
\stackrel{2}{\alpha}\end{array}$ & $\begin{array}{c}1+ \\
2 \\
\alpha \\
\alpha\end{array}$ & $\begin{array}{l}\infty \\
\sim \\
\sim \\
\sim\end{array} \mid$ & $\mid \begin{array}{c}\tilde{\sigma} \\
\tilde{\sigma}\end{array}$ & $\begin{array}{l}\infty \\
\approx \\
\sim \\
\sim\end{array}$ & 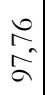 & $\begin{array}{c}2 \\
\infty \\
\infty\end{array}$ & $\begin{array}{l}\hat{n} \\
\hat{n} \\
-\end{array}$ & $\left|\begin{array}{c}\infty \\
\infty \\
\infty\end{array}\right|$ & $\frac{2}{\infty}$ \\
\hline
\end{tabular}




\begin{tabular}{|c|c|c|c|c|c|c|c|c|c|c|c|c|c|c|c|}
\hline $\begin{array}{l}\text { Factor / } \\
\text { foreign market }\end{array}$ & 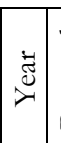 & 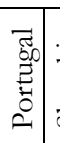 & $\begin{array}{l}\frac{\pi}{d} \\
\frac{\pi}{n} \\
\frac{0}{\omega}\end{array}$ & 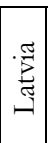 & $\begin{array}{l}\vec{\Xi} \\
\stackrel{\vec{Z}}{\Xi} \\
\text { 声 }\end{array}$ & $\begin{array}{l}\text {. } \\
\text { مै } \\
\text { की }\end{array}$ & 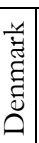 & 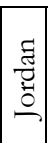 & 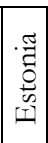 & 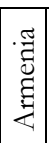 & 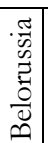 & 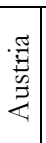 & $\frac{\pi}{\pi}$ & 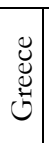 & . \\
\hline 1 & 2 & 3 & 4 & 5 & 6 & 7 & 8 & 9 & 10 & 11 & 12 & 13 & 14 & 15 & 16 \\
\hline \multirow{2}{*}{ Openness of trade, (export + import) $\%$ of GDP } & 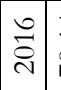 & $\begin{array}{l} \pm \\
\stackrel{2}{\curvearrowright}\end{array}$ & $\begin{array}{l}\infty \\
\infty \\
\infty \\
\infty \\
\sim\end{array}$ & $\begin{array}{l}\mathcal{N} \\
\stackrel{\Omega}{=} \\
=\end{array}$ & $\begin{array}{l}\infty \\
\mathfrak{N} \\
\mathfrak{N}\end{array}$ & $\hat{\hat{\sigma}}$ & $\tilde{\delta}^{\prime}$ & $\begin{array}{l}\hat{2} \\
\stackrel{2}{-}\end{array}$ & $\begin{array}{l}\vec{f} \\
\stackrel{f}{2} \\
\sim\end{array}$ & 吕 & $\begin{array}{l}\stackrel{\sim}{\sim} \\
\stackrel{\sim}{\sim} \\
\sim\end{array}$ & 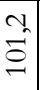 & 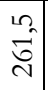 & $\begin{array}{l}\vec{J}_{n} \\
\vec{\sigma}\end{array}$ & $\begin{array}{l}0 \\
\text { nn }\end{array}$ \\
\hline & 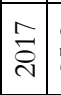 & $\begin{array}{c}0 \\
1 \\
\infty \\
\infty\end{array}$ & $\begin{array}{l}\vec{\circ} \\
\infty \\
-\end{array}$ & $\begin{array}{l}\stackrel{m}{2} \\
\stackrel{f}{\sim} \\
\end{array}$ & 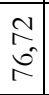 & 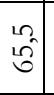 & $\begin{array}{l}\forall_{n} \\
\stackrel{0}{0} \\
\ddots\end{array}$ & $\begin{array}{l}0 \\
\hat{\alpha} \\
\end{array}$ & $\begin{array}{c}0 \\
\stackrel{0}{n} \\
-\end{array}$ & \begin{tabular}{|l|}
2 \\
$\infty$ \\
$\infty$ \\
$\infty$
\end{tabular} & $\begin{array}{l}\stackrel{0}{n} \\
\stackrel{\overbrace{}}{\sim}\end{array}$ & 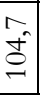 & 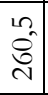 & 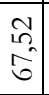 & 㐫 \\
\hline \multirow{2}{*}{ Direct foreign investments, $\%$ to GDP } & 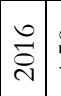 & \begin{tabular}{l}
$\stackrel{2}{n}$ \\
\multirow{+}{*}{}
\end{tabular} & 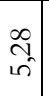 & $\mid \begin{array}{l}\infty \\
\infty \\
0 \\
0\end{array}$ & $\stackrel{\infty}{\rightarrow}$ & $\vec{\sim}$ & 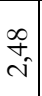 & $\begin{array}{c}0 \\
o \\
+ \\
+\end{array}$ & $\mid \begin{array}{l}0 \\
0 \\
+\end{array}$ & $\mid \begin{array}{c}\vec{N} \\
\hat{n}\end{array}$ & $\begin{array}{l}\vec{\sigma} \\
i\end{array}$ & $\stackrel{m}{2}$ & $\begin{array}{l}\hat{\hat{v}} \\
\overrightarrow{\hat{v}}\end{array}$ & $\stackrel{q}{q}$ & $\stackrel{\circ}{\sim}$ \\
\hline & $\overrightarrow{\hat{s}}$ & \begin{tabular}{l}
$\vec{\sigma}$ \\
\multirow{r}{*}{}
\end{tabular} & $\stackrel{\infty}{*}$ & $\begin{array}{l}0 \\
2 \\
m\end{array}$ & $\begin{array}{l}t_{n} \\
i n\end{array}$ & $\begin{array}{l}\text { f } \\
0\end{array}$ & $\stackrel{m}{\tilde{0}}$ & \begin{tabular}{|c|} 
\\
1 \\
$i n$
\end{tabular} & $\hat{0}_{0}$ & $\mid \begin{array}{c}0 \\
\stackrel{1}{i}\end{array}$ & $\begin{array}{c}\mathrm{w} \\
\mathrm{v}\end{array}$ & $\begin{array}{l}\stackrel{2}{r} \\
m\end{array}$ & $\begin{array}{l}n \\
0 \\
\hat{N}\end{array}$ & $\begin{array}{l}\infty \\
\stackrel{\infty}{\sim} \\
\sim\end{array}$ & $\stackrel{n}{\sim}$ \\
\hline \multicolumn{16}{|c|}{ Management and political system } \\
\hline \multirow[b]{2}{*}{ Government Effectiveness } & 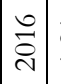 & $\overrightarrow{\vec{\sim}}$ & $\overrightarrow{0}$ & $\stackrel{\overrightarrow{0}}{-}$ & $\begin{array}{l}\hat{\infty} \\
\stackrel{\infty}{-}\end{array}$ & $\stackrel{\sim}{\cong}$ & $\stackrel{\sim}{\sim}$ & $\stackrel{\overrightarrow{0}}{0}$ & $\Rightarrow$ & \begin{tabular}{|c|}
$n$ \\
0 \\
0 \\
1
\end{tabular} & 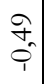 & $\stackrel{\vec{n}}{\sim}$ & $\stackrel{0}{\circ}$ & $\hat{\tilde{n}}$ & m. \\
\hline & $\overrightarrow{\vec{\sigma}}$ & $\stackrel{m}{\rightarrow}$ & $\vec{\infty}$ & $\hat{\sigma}$ & $\stackrel{ \pm}{\sigma}$ & $\hat{\theta}$ & $\stackrel{\infty}{\rightarrow}$ & $\stackrel{2}{2}$ & $\cong$ & $\overrightarrow{0}$ & $\begin{array}{c}n \\
\tilde{c} \\
\rho_{1}^{n}\end{array}$ & 年 & $\stackrel{\circ}{-}$ & $\overrightarrow{3}$ & $\stackrel{\text { Tे }}{6}$ \\
\hline \multirow{2}{*}{ Corruption Control Factor } & 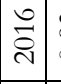 & $\cong$ & $\hat{\imath}$ & $\stackrel{m}{\tilde{g}}$ & 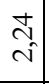 & م્ & $\tilde{i}$ & $\begin{array}{l}\hat{n} \\
\hat{0} \\
\end{array}$ & $\hat{\imath}$ & \begin{tabular}{|l|l}
0 \\
0 \\
0 \\
$i$
\end{tabular} & $\begin{array}{l}\text { స̂. } \\
\text { î. } \\
\end{array}$ & 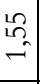 & $\mid \begin{array}{c}0 \\
\mathfrak{N} \\
\end{array}$ & $\begin{array}{l}0 \\
\hat{0} \\
\hat{i}\end{array}$ & ? \\
\hline & 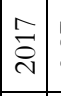 & $\begin{array}{l}n \\
\infty \\
0\end{array}$ & กิ & $\begin{array}{c}1 \\
0 \\
0 \\
0\end{array}$ & $\begin{array}{l}\tilde{N} \\
\text { i }\end{array}$ & $\begin{array}{l}\stackrel{g}{G} \\
0\end{array}$ & $\stackrel{\vec{\imath}}{\mathrm{i}}$ & în. & $\stackrel{+}{\sim}$ & $\begin{array}{l}0 \\
1 \\
0 \\
0 \\
1\end{array}$ & 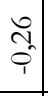 & $\stackrel{n}{\sim}$ & $\frac{\Delta}{\tilde{O}}$ & $\begin{array}{c} \pm \\
\overrightarrow{0} \\
i\end{array}$ & ?े \\
\hline \multirow{2}{*}{ Quality coefficient of legislative regulation } & 号 & $\begin{array}{l}+ \\
\infty \\
0\end{array}$ & $\begin{array}{c}\infty \\
0^{\prime} \\
0\end{array}$ & 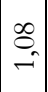 & $\stackrel{\substack{0 \\
\rightarrow}}{\rightarrow}$ & $\begin{array}{c}\vec{\sigma} \\
\rightarrow\end{array}$ & 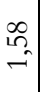 & $\begin{array}{l}\stackrel{n}{0} \\
0 \\
0\end{array}$ & $\stackrel{\sim}{\sim}$ & 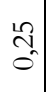 & 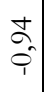 & $\begin{array}{l}J_{n} \\
\rightarrow\end{array}$ & $\begin{array}{l}0 \\
\Rightarrow \\
-\end{array}$ & $\begin{array}{l}n \\
0\end{array}$ & ?ै \\
\hline & 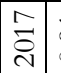 & $\overrightarrow{\sigma_{0}}$ & $\begin{array}{l}1 \\
\infty \\
0 \\
0\end{array}$ & $\stackrel{20}{=}$ & $\begin{array}{c}\stackrel{\sim}{\infty} \\
\rightarrow \\
\rightarrow\end{array}$ & 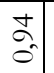 & $\underset{\sim}{\mathbb{\sigma}}$ & $\overrightarrow{0}$ & $\begin{array}{c}\mathbb{G} \\
\rightarrow \\
-\end{array}$ & \begin{tabular}{|c|}
$\infty$ \\
0 \\
0 \\
0
\end{tabular} & 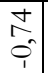 & $\underset{\sim}{J_{-}}$ & \begin{tabular}{l} 
\\
\multirow{-}{*}{} \\
-
\end{tabular} & $\begin{array}{l}\vec{J} \\
\text { Oै }\end{array}$ & ô \\
\hline \multirow[b]{2}{*}{ Index of Law Rule, points } & 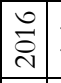 & $\Rightarrow$ & $\begin{array}{l}2 \\
0 \\
0 \\
0\end{array}$ & \begin{tabular}{l} 
\\
\hdashline \\
\end{tabular} & $\begin{array}{l}\mathrm{d} \\
\mathrm{d} \\
\mathrm{i}\end{array}$ & $\begin{array}{l}\infty \\
\stackrel{2}{0} \\
\stackrel{2}{2}\end{array}$ & $\vec{\sigma}$ & $\hat{0}^{2}$ & $\stackrel{\imath}{-}$ & \begin{tabular}{|c|} 
\\
\\
0 \\
1 \\
\end{tabular} & $\begin{array}{l}N \\
\hat{0} \\
i \\
\end{array}$ & $\begin{array}{ll}0 \\
\infty \\
- \\
-\end{array}$ & $\stackrel{0}{-}$ & $\overrightarrow{0}$ & ? \\
\hline & \begin{tabular}{|l|}
\multirow{2}{*}{} \\
\end{tabular} & $\begin{array}{l}m \\
\Rightarrow\end{array}$ & in & $\tilde{\tilde{\sigma}}$ & $\begin{array}{l} \\
\hat{\sigma} \\
\hat{v}\end{array}$ & $\begin{array}{l}\vec{\sigma} \\
\rightarrow\end{array}$ & $\stackrel{\circ}{\circ}$ & \begin{tabular}{l}
0 \\
\multirow{2}{*}{} \\
0
\end{tabular} & $\stackrel{\substack{1 \\
\sim}}{-}$ & \begin{tabular}{|l|}
0 \\
$\stackrel{0}{0}$ \\
\\
1
\end{tabular} & $\begin{array}{l}0 \\
\infty \\
\varphi_{1}\end{array}$ & $\stackrel{\substack{\infty \\
-}}{\infty}$ & $\stackrel{\Xi}{=}$ & $\begin{array}{l}\infty \\
0_{n}^{\prime} \\
0\end{array}$ & ?) \\
\hline \multicolumn{16}{|c|}{ Economic freedom } \\
\hline \multirow{3}{*}{ Index of Business of Freedom, points } & 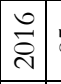 & $\infty$ & 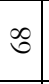 & $\Re$ & $\bar{a}$ & $\stackrel{0}{r}$ & 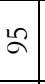 & 10 & $\curvearrowright$ & $\infty$ & gे & $\curvearrowright$ & สิ & 咅 & 華 \\
\hline & 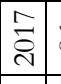 & $\infty$ & : & $\infty$ & $\AA$ & 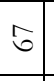 & 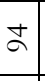 & t & $尺$ & $\curvearrowright$ & $\vec{r}$ & $\curvearrowright$ & $\tilde{\sigma}$ & 咅 & in \\
\hline & $\mid \begin{array}{l}\infty \\
\vec{\sim} \\
\vec{\sim}\end{array}$ & $\infty$ & t & $\infty$ & ฉ & ఠర & $\approx$ & $\tilde{\sigma}$ & ㄴ. & $\Re$ & 共 & $\stackrel{\circ}{\sim}$ & $\overleftarrow{b}$ & 亲 & $\stackrel{1}{n}$ \\
\hline \multirow{3}{*}{ Index of Trade Freedom, points } & 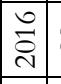 & \begin{tabular}{l|l}
$\infty$ & $\infty$ \\
$\infty$ & 1
\end{tabular} & $\infty$ & $\begin{array}{ll}\infty \\
\infty\end{array}$ & $\begin{array}{l}\infty \\
\infty\end{array}$ & $\infty$ & $\infty$ & $\Re$ & $\infty$ & $\infty$ & $\Re$ & $\infty$ & $\infty$ & $\infty$ & $\stackrel{m}{r}$ \\
\hline & $\mid \begin{array}{c}\hat{\sigma} \\
\vec{\sigma}\end{array}$ & $\infty$ & $\infty$ & $\infty$ & $\infty$ & $\infty$ & $\infty$ & $\infty$ & $\infty$ & $\infty$ & $\bar{\infty}$ & $\infty$ & $\infty$ & $\infty$ & ন \\
\hline & 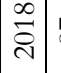 & $\infty$ & $\infty$ & $\mid \infty$ & $\infty$ & $\hat{\infty}^{\circ}$ & $\infty$ & 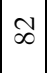 & $\infty$ & $\infty$ & $\vec{\infty}$ & $\infty$ & $\infty$ & 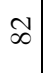 & $\stackrel{m}{r}$ \\
\hline
\end{tabular}




\begin{tabular}{|c|c|c|c|c|c|c|c|c|c|c|c|c|c|c|c|}
\hline $\begin{array}{l}\text { Factor / } \\
\text { foreign market }\end{array}$ & 节 & 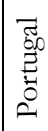 & 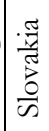 & 茎 & $\begin{array}{c}\vec{\Xi} \\
\text { ज्ञ } \\
\text { 诘 }\end{array}$ & $\begin{array}{l}\text { : } \\
\text { की }\end{array}$ & 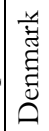 & 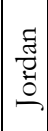 & 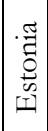 & 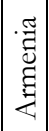 & 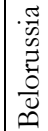 & 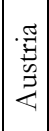 & $\frac{\pi}{\pi}$ & 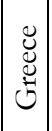 & 茎 \\
\hline 1 & 2 & 3 & 4 & 5 & 6 & 7 & 8 & 9 & 10 & 11 & 12 & 13 & 14 & 15 & 16 \\
\hline \multirow{3}{*}{ Index of economic freedom, points } & $\begin{array}{l}0 \\
\overrightarrow{\tilde{s}} \\
\end{array}$ & 每 & 6 & $R$ & 2 & is & $\stackrel{2 n}{n}$ & $\infty$ & $尺$ & 10 & $\stackrel{\infty}{i n}$ & $\stackrel{1}{2}$ & 10 & $\hat{n}$ & กิ \\
\hline & 를 & 3 & : & $\stackrel{2 n}{n}$ & $\frac{1}{4}$ & t & $\stackrel{2}{n}$ & $\hat{0}$ & $\Re$ & $尺$ & $\stackrel{\infty}{\infty}$ & $\stackrel{1}{N}$ & $\infty$ & in & in \\
\hline & $\begin{array}{l}\infty \\
\overrightarrow{\tilde{d}} \\
\end{array}$ & 3 & $\mid \frac{1}{4}$ & $\frac{5}{4}$ & $\frac{1}{4}$ & 10 & 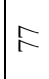 & 20 & $\Re$ & 9 & $\stackrel{\infty}{i n}$ & $\stackrel{1}{N}$ & )े & in & $\stackrel{\infty}{i}$ \\
\hline \multirow{2}{*}{ Share of agriculture in GDP, $\%$} & 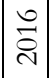 & 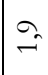 & $\stackrel{2}{2}$ & $\begin{array}{c}\stackrel{T}{+} \\
\sim \\
m\end{array}$ & $\vec{n}$ & in & 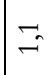 & $\begin{array}{l}\Re \\
\tilde{r} \\
m\end{array}$ & $\mathfrak{v}$ & $\begin{array}{c}2 \\
\hat{2} \\
\sigma_{-1}^{2}\end{array}$ & $\hat{\sigma}_{\text {f }}$ & $\Rightarrow$ & $\stackrel{\circ}{-}$ & $\mid \begin{array}{c}0 \\
+ \\
n \\
m\end{array}$ & $\begin{array}{l}\stackrel{\circ}{\circ} \\
\infty\end{array}$ \\
\hline & $\overrightarrow{\tilde{s}}$ & $\Leftrightarrow$ & $\begin{array}{l}\stackrel{2}{n} \\
\text { nn }\end{array}$ & $\stackrel{+}{m}$ & ?ै & in & $\stackrel{n}{=}$ & $\begin{array}{l}\tilde{\sigma} \\
+\end{array}$ & $\mid$ & $\begin{array}{l}\dot{J} \\
\stackrel{2}{-} \\
\dot{\sim}\end{array}$ & $\stackrel{尺}{r}$ & $\stackrel{\cong}{=}$ & $\mid$ & $\begin{array}{l}\hat{n} \\
\hat{n} \\
m\end{array}$ & $\stackrel{\Omega}{\Omega}$ \\
\hline \multirow{3}{*}{ Index of innovations, points } & $\begin{array}{l}0 \\
\overrightarrow{2} \\
\tilde{c}\end{array}$ & $\begin{array}{l}t_{n} \\
\sigma^{+}\end{array}$ & $\vec{F}$ & $\begin{array}{l}2 \\
f^{2}\end{array}$ & हैं & $\underline{\mathfrak{q}}$ & $\begin{array}{l}10 \\
\infty 0^{n} \\
10\end{array}$ & $\begin{array}{l}0 \\
0 \\
0\end{array}$ & $\vec{n}$ & $\begin{array}{c}\overrightarrow{2} \\
n \\
n\end{array}$ & ڤn & $\begin{array}{l}0 \\
i \\
\text { in }\end{array}$ & 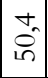 & $\begin{array}{l}\infty \\
\infty \\
\infty\end{array}$ & : \\
\hline & \begin{tabular}{|l|}
\multirow{2}{*}{} \\
ㄱ.
\end{tabular} & $\vec{f}$ & $\dot{q}$ & $\begin{array}{l}0 \\
f \\
f\end{array}$ & $\begin{array}{l}10 \\
\infty \\
\infty\end{array}$ & $\begin{array}{l}\infty \\
\infty \\
\infty\end{array}$ & $\begin{array}{l}n^{\circ} \\
\infty \\
i n\end{array}$ & \begin{tabular}{|l|}
$n$ \\
$\hat{n}$ \\
$\tilde{n}$
\end{tabular} & $\begin{array}{l}\hat{\theta} \\
\hat{n}\end{array}$ & \begin{tabular}{|l|} 
\\
$m$ \\
$m$
\end{tabular} & $\begin{array}{l}0 \\
\stackrel{n}{n}\end{array}$ & $\vec{n}$ & \begin{tabular}{|l|}
0 \\
$\circ$ \\
in
\end{tabular} & \begin{tabular}{|l|}
$\infty$ \\
$\infty$ \\
$\infty$
\end{tabular} & $\begin{array}{l}\text { in } \\
\text { กิ }\end{array}$ \\
\hline & \begin{tabular}{|l|}
$\infty$ \\
$\vec{i}$ \\
\end{tabular} & $\begin{array}{l}\hat{n} \\
\dot{f} \\
\end{array}$ & $\hat{\text { f }}$ & $\begin{array}{l}1 \\
\tilde{f} \\
\tilde{f}\end{array}$ & $\begin{array}{l}0 \\
\text { in }\end{array}$ & \begin{tabular}{l}
\multicolumn{1}{c}{} \\
of \\
$\stackrel{+}{+}$
\end{tabular} & $\begin{array}{l}t_{n} \\
\infty \\
i n \\
\end{array}$ & $\begin{array}{l}\infty \\
0 \\
\rho_{n}\end{array}$ & $\begin{array}{l}n \\
8 \\
\text { in } \\
\end{array}$ & \begin{tabular}{|l|}
$\infty$ \\
n \\
$m$
\end{tabular} & $\vec{i}$ & $\stackrel{n}{i n}$ & in & $\begin{array}{l}2 \\
\infty \\
\tilde{n}^{-}\end{array}$ & ली \\
\hline \multirow{3}{*}{ Profit tax rate, $\%$} & 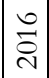 & $\begin{array}{l}\infty \\
\stackrel{m}{m}\end{array}$ & हn & $\begin{array}{l}\hat{n} \\
\tilde{m}\end{array}$ & $\begin{array}{l}+ \\
\infty \\
\infty\end{array}$ & $\begin{array}{l}\hat{\sigma} \\
\dot{f}\end{array}$ & $\begin{array}{l}\infty \\
\approx\end{array}$ & $\overrightarrow{\widehat{\sim}}$ & $\begin{array}{c}\stackrel{\sim}{0} \\
\stackrel{0}{+}\end{array}$ & $\begin{array}{l}1^{n} \\
\infty \\
-\end{array}$ & $\hat{\hat{N}}$ & $\begin{array}{l}\infty \\
\overrightarrow{i n}\end{array}$ & $\begin{array}{c}\stackrel{\sim}{\sim} \\
\stackrel{f}{\sigma}\end{array}$ & 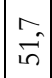 & $\frac{2}{6}$ \\
\hline & $\overrightarrow{\tilde{\sigma}}$ & $\begin{array}{l}\infty \\
\stackrel{\infty}{2}\end{array}$ & $\overrightarrow{0}$ & $\begin{array}{c}\hat{n} \\
\hat{m}\end{array}$ & 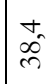 & $\hat{\sigma}$ & 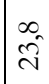 & $\mid \begin{array}{l}\overrightarrow{0} \\
\stackrel{0}{v}\end{array}$ & $\begin{array}{l}r \\
\infty \\
+ \\
+\end{array}$ & $\begin{array}{l}L_{0} \\
\infty \\
-1\end{array}$ & तิ & $\begin{array}{l}\infty \\
\stackrel{\infty}{i n}\end{array}$ & $\begin{array}{c}\tilde{f} \\
\stackrel{f}{f}\end{array}$ & $\overrightarrow{\hat{n}}$ & $\frac{2}{6}$ \\
\hline & \begin{tabular}{|l|} 
\\
$\overrightarrow{\tilde{\sigma}}$ \\
\end{tabular} & $\begin{array}{l}\infty \\
\hat{m}\end{array}$ & $\hat{q}$ & $\begin{array}{l}0 \\
0 \\
\tilde{n}^{n}\end{array}$ & $\begin{array}{l}n \\
\tilde{n}\end{array}$ & $\begin{array}{l}0 \\
f \\
f\end{array}$ & $\begin{array}{l}\infty \\
\approx\end{array}$ & $\begin{array}{l}0 \\
0 \\
00^{n}\end{array}$ & 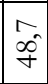 & $\begin{array}{l}n \\
\infty \\
\infty \\
\end{array}$ & $\begin{array}{l}n \\
\hat{n} \\
\hat{n}\end{array}$ & $\begin{array}{l}10 \\
i n \\
i n\end{array}$ & $\begin{array}{l}0 \\
f \\
f\end{array}$ & $\stackrel{a}{i n}$ & $\begin{array}{l}\text { वे } \\
\text { fol }\end{array}$ \\
\hline \multirow{3}{*}{ The index of life quality of the population } & $\begin{array}{l}0 \\
\overrightarrow{\tilde{d}} \\
\text { | }\end{array}$ & $\underset{\sim 0}{\stackrel{N}{2}}$ & $\begin{array}{l}\infty \\
0 \\
0\end{array}$ & $\begin{array}{l}0 \\
2 n \\
i n\end{array}$ & $\begin{array}{l}\vec{\sigma} \\
\text { in }\end{array}$ & ?. & ñn & $\begin{array}{l}2 \\
n^{2}\end{array}$ & $\begin{array}{l}N \\
\tilde{n} \\
10\end{array}$ & $\begin{array}{l}2 \\
i \\
\sigma^{2}\end{array}$ & $\begin{array}{l}\infty \\
\infty \\
10\end{array}$ & $\stackrel{\sim}{\stackrel{2}{\sim}}$ & $\begin{array}{l}\stackrel{\vartheta}{\mathcal{f}_{0}} \\
\mathbf{n}^{\prime}\end{array}$ & $\begin{array}{c}\tilde{\delta} \\
\hat{0} \\
10\end{array}$ & $\begin{array}{l}\text { in } \\
\text { in }\end{array}$ \\
\hline & 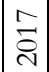 & $\begin{array}{l}N \\
i n\end{array}$ & 5 & $\begin{array}{l}10 \\
\infty \\
10\end{array}$ & $\underset{\sim}{\stackrel{F}{\sim}}$ & $\sigma_{0}^{+}$ & N & $\begin{array}{l}\mathbf{H} \\
\text { in } \\
\text { in }\end{array}$ & $\begin{array}{c}\overrightarrow{6} \\
\dot{0}\end{array}$ & $\begin{array}{l}\infty \\
\stackrel{2}{2} \\
\overbrace{}^{2}\end{array}$ & $\begin{array}{l}\hat{n} \\
\text { in }\end{array}$ & $\sigma_{0}$ & $\begin{array}{c}\tilde{n} \\
\hat{n}\end{array}$ & $\tilde{\imath}$ & స̂. \\
\hline & $\frac{\infty}{\tilde{\sigma}}$ & $\begin{array}{l}\vec{r} \\
\text { in }\end{array}$ & 긍 & $\begin{array}{c}2 \\
\tilde{n}^{\prime}\end{array} \mid$ & $\tilde{\sigma}$ & $\overline{\hat{\sigma}}$ & $\begin{array}{l}\stackrel{0}{2} \\
\stackrel{n}{n}\end{array}$ & $\begin{array}{c}0 \\
2 \\
10\end{array}$ & $\begin{array}{l}+⿱ 亠 䒑 \\
i n \\
i n\end{array}$ & $\left|\begin{array}{c}\sqrt{2} \\
\tilde{f}\end{array}\right|$ & $\begin{array}{l}\infty \\
\stackrel{+}{+} \\
\text { மn }\end{array}$ & $\underset{\sim}{\stackrel{\Xi}{\sim}}$ & $\begin{array}{l}3 \\
\hat{\sigma} \\
\sigma_{0}\end{array}$ & $\mid \begin{array}{l}0 \\
2 \\
2 \\
10\end{array}$ & $\begin{array}{l}\text { ?n } \\
\text { in }\end{array}$ \\
\hline
\end{tabular}

Source: compiled by the author for (Global Economy, Trade Statistics for International Business Development) [23-25]

Analyzing the information provided by the World Bank, the Eurasian Development Bank and developing indicators for assessing the possibilities of implementing the chosen internationalization strategy by Ukrainian meat producers, we will assess the attractiveness of the business environment of the new international markets for Ukrainian meat producers (Chart 14). A group of ten experts was ranked on the basis of the summation method of the ranks predefined as potential markets in the 5 scale (estimated scale) [23-25]. 
Chart 14. Ranking of international markets on the basis of ranks summation of indicators of attractiveness of their business environment for Ukrainian meat producers by the product group "0207 Poultry", 2016-2018.

\begin{tabular}{|c|c|c|c|c|c|c|c|c|c|c|c|c|c|c|}
\hline Factor / foreign market & Year & $\begin{array}{l}\overrightarrow{\overrightarrow{5}} \\
\stackrel{5}{0} \\
\underline{3} \\
0 \\
0\end{array}$ & $\begin{array}{l}\frac{\pi}{n} \\
\frac{\pi}{\pi} \\
\overrightarrow{0} \\
\frac{0}{n}\end{array}$ & 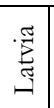 & 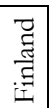 & $\begin{array}{l}\text {. } \\
\text { है } \\
\text { है }\end{array}$ & - & 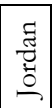 & 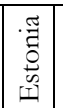 & 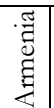 & 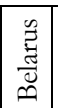 & 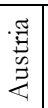 & $\frac{\pi}{\sqrt[3]{2}}$ & $\begin{array}{l}\mathscr{U} \\
\stackrel{\mathscr{U}}{0}\end{array}$ \\
\hline \multirow{2}{*}{ Economic growth, \% } & 2016 & 2 & 3 & 2 & 2 & 3 & 2 & 2 & 2 & 2 & 1 & 2 & 3 & 1 \\
\hline & 2017 & 2 & 3 & 3 & 2 & 2 & 2 & 2 & 3 & 4 & 2 & 2 & 3 & 2 \\
\hline \multirow{2}{*}{ GDP at current prices, billion dollars } & 2016 & 2 & 2 & 2 & 2 & 2 & 2 & 2 & 2 & 2 & 2 & 2 & 2 & 2 \\
\hline & 2017 & 2 & 2 & 2 & 2 & 3 & 2 & 2 & 2 & 2 & 2 & 2 & 2 & 2 \\
\hline \multirow{2}{*}{$\begin{array}{l}\text { Per capita GDP, per purchasing power parity, } \\
\text { thousand dollars / person }\end{array}$} & 2016 & 2 & 2 & 2 & 3 & 2 & 4 & 2 & 3 & 2 & 2 & 3 & 3 & 3 \\
\hline & 2017 & 3 & 2 & 3 & 4 & 3 & 4 & 2 & 2 & 2 & 4 & 4 & 3 & 3 \\
\hline \multirow{2}{*}{ Inflation rate (by consumer price index) } & 2016 & 5 & 5 & 5 & 5 & 5 & 5 & 5 & 5 & 5 & 3 & 5 & 5 & 5 \\
\hline & 2017 & 4 & 4 & 4 & 5 & 4 & 5 & 4 & 4 & 5 & 3 & 4 & 4 & 4 \\
\hline \multirow{2}{*}{ Household consumption, $\%$} & 2016 & 4 & 4 & 4 & 4 & 4 & 4 & 4 & 4 & 4 & 4 & 4 & 3 & 4 \\
\hline & 2017 & 4 & 4 & 4 & 4 & 4 & 3 & 4 & 4 & 4 & 4 & 4 & 3 & 4 \\
\hline \multirow{2}{*}{ Savings, $\%$ of GDP } & 2016 & 4 & 4 & 4 & 4 & 4 & 4 & 4 & 4 & 4 & 4 & 4 & 4 & 4 \\
\hline & 2017 & 4 & 4 & 4 & 4 & 4 & 4 & 4 & 4 & 4 & 4 & 4 & 4 & 4 \\
\hline \multirow{2}{*}{ Terms of trade, $\%$} & 2016 & 3 & 3 & 3 & 3 & 3 & 3 & 2 & 3 & 3 & 3 & 3 & 4 & 3 \\
\hline & 2017 & 3 & 3 & 3 & 3 & 3 & 3 & 3 & 3 & 4 & 3 & 3 & 4 & 3 \\
\hline \multirow{2}{*}{$\begin{array}{l}\text { Openness of trade, (export + import) } \% \text { of } \\
\text { GDP }\end{array}$} & 2016 & 2 & 3 & 3 & 2 & 2 & 3 & 2 & 3 & 2 & 3 & 2 & 4 & 2 \\
\hline & 2017 & 2 & 3 & 3 & 2 & 2 & 3 & 2 & 3 & 2 & 3 & 2 & 4 & 2 \\
\hline \multirow{2}{*}{ Direct foreign investments, $\%$ to GDP } & 2016 & 3 & 3 & 3 & 3 & 3 & 3 & 3 & 3 & 3 & 3 & 1 & 4 & 2 \\
\hline & 2017 & 3 & 3 & 3 & 3 & 1 & 1 & 3 & 3 & 2 & 2 & 2 & 4 & 2 \\
\hline \multirow{2}{*}{ Government Effectiveness } & 2016 & 4 & 2 & 3 & 4 & 3 & 3 & 2 & 3 & 1 & 1 & 3 & 2 & 2 \\
\hline & 2017 & 3 & 2 & 2 & 3 & 3 & 3 & 1 & 3 & 1 & 1 & 2 & 2 & 2 \\
\hline \multirow{2}{*}{ Corruption Control Factor } & 2016 & 4 & 3 & 3 & 5 & 2 & 4 & 2 & 3 & 1 & 1 & 4 & 3 & 1 \\
\hline & 2017 & 4 & 2 & 2 & 5 & 2 & 5 & \begin{tabular}{|l|}
2 \\
\end{tabular} & 3 & 1 & 1 & 4 & 3 & 1 \\
\hline \multirow{2}{*}{ Coefficient of quality of legislative regulation } & 2016 & 4 & 4 & 4 & 4 & 4 & 4 & 4 & 4 & 4 & 1 & 4 & 4 & 3 \\
\hline & 2017 & 3 & 3 & 3 & 4 & 3 & 4 & 2 & \begin{tabular}{|l|}
4 \\
\end{tabular} & 2 & 1 & 4 & 4 & 2 \\
\hline \multirow{2}{*}{ Index of Rule of Law, scores } & 2016 & 4 & 3 & 3 & \begin{tabular}{|l|}
5 \\
\end{tabular} & 4 & 4 & 3 & 3 & 1 & 1 & 3 & 2 & 2 \\
\hline & \begin{tabular}{|l|}
2017 \\
\end{tabular} & 3 & 2 & 2 & 5 & 3 & \begin{tabular}{|l|}
4 \\
\end{tabular} & \begin{tabular}{|l|}
2 \\
\end{tabular} & 2 & 1 & 1 & 3 & 2 & 2 \\
\hline \multirow{3}{*}{ Index of Business Freedom, scores } & 2016 & 4 & 3 & 4 & 5 & 4 & 5 & 3 & 4 & 4 & 3 & 4 & 3 & 4 \\
\hline & 2017 & 4 & 3 & 4 & 5 & 3 & \begin{tabular}{|l|}
5 \\
\end{tabular} & 3 & \begin{tabular}{|l|}
4 \\
\end{tabular} & 4 & 4 & 4 & 3 & 3 \\
\hline & 2018 & 4 & 3 & 4 & 5 & 3 & 5 & 3 & 4 & 4 & 4 & 4 & 3 & 4 \\
\hline \multirow{3}{*}{ Index of Freedom of Trade, scores } & 2016 & 5 & 5 & 5 & 5 & 5 & 5 & 4 & 5 & 5 & 4 & 5 & 5 & 4 \\
\hline & 2017 & 5 & 5 & 5 & 5 & 5 & 5 & 5 & 5 & 5 & 5 & 5 & 5 & 5 \\
\hline & 2018 & 5 & 5 & 5 & 5 & 5 & 5 & 5 & 5 & 5 & 5 & 5 & 5 & 5 \\
\hline \multirow{3}{*}{ Index of economic freedom, scores } & 2016 & 4 & 4 & 4 & 4 & 4 & 4 & 4 & 4 & 4 & 3 & 4 & 3 & 3 \\
\hline & 2017 & 4 & 4 & 4 & 4 & 3 & 4 & 3 & 4 & 4 & 3 & 4 & 4 & 3 \\
\hline & 2018 & 4 & 4 & 4 & 4 & 3 & 4 & 3 & 4 & 4 & 3 & 4 & 4 & 3 \\
\hline \multirow{2}{*}{ Agriculture share in GDP, $\%$} & 2016 & 4 & 4 & 4 & 4 & 4 & 4 & 4 & 4 & 3 & 4 & 4 & 4 & 4 \\
\hline & 2017 & 4 & 4 & 4 & 4 & 4 & 4 & 4 & 4 & 3 & 4 & 4 & 4 & 4 \\
\hline \multirow{3}{*}{ Index of innovations, points } & 2016 & 4 & 4 & 4 & 5 & 4 & 5 & 3 & 4 & 3 & 3 & 4 & 4 & 3 \\
\hline & 2017 & 4 & 4 & 4 & 3 & 4 & 5 & 3 & 4 & 3 & 3 & 4 & 4 & 3 \\
\hline & 2018 & 4 & 4 & 4 & 4 & 4 & 4 & 3 & 4 & 3 & 3 & 4 & 4 & 3 \\
\hline & 2016 & 4 & 4 & 4 & 4 & 4 & 4 & 4 & 4 & 4 & 4 & 4 & 4 & 4 \\
\hline Profit tax rate, $\%$ & 2017 & 4 & 4 & 4 & 4 & 4 & 4 & 4 & 4 & 4 & 4 & 4 & 4 & 4 \\
\hline & 2018 & 4 & 4 & 4 & 4 & 4 & 4 & 4 & 4 & 4 & 4 & 4 & 4 & 4 \\
\hline & 2016 & 4 & 4 & 4 & 4 & 4 & 5 & 4 & 4 & 4 & 4 & 5 & 5 & 4 \\
\hline The index of quality of population life & 2017 & 4 & 5 & 4 & 5 & 5 & 5 & 4 & 4 & 4 & 5 & 5 & 5 & 4 \\
\hline & 2018 & 4 & 5 & 4 & 5 & 5 & 5 & 4 & 4 & 4 & 4 & 5 & 5 & 4 \\
\hline Total & & 166 & 160 & 162 & 180 & 159 & 179 & 144 & 165 & 146 & 136 & 166 & 167 & 142 \\
\hline
\end{tabular}

Source: compiled by author for (Global Economy, Organization for Economic Cooperation and Development, World Economy, World Finance, World Markets) [23-26]. 
The average, the largest and the smallest global value of each indicator (1-2 - the minimum value, 3-4 - the average value, 5 - the maximum value) was taken into account when compiling the evaluation chart, the summing method defines the general index of each market, the maximum value of which is evidenced by more favorable conditions for domestic enterprises exit into it.

\section{Discussion on Future Prospects}

As a result of the survey by summing up the ranks on the above indicators, it was found that the markets of Denmark, Malta, Finland had showed favorable conditions for doing business on them, which was a prerequisite for the exit of Ukrainian meat producers into the markets of these countries. That is, the application of mentioned above approach made it possible to develop a target portfolio for further targeting the implementation of the strategy of internationalization by Ukrainian meat producers (Fig. 6).

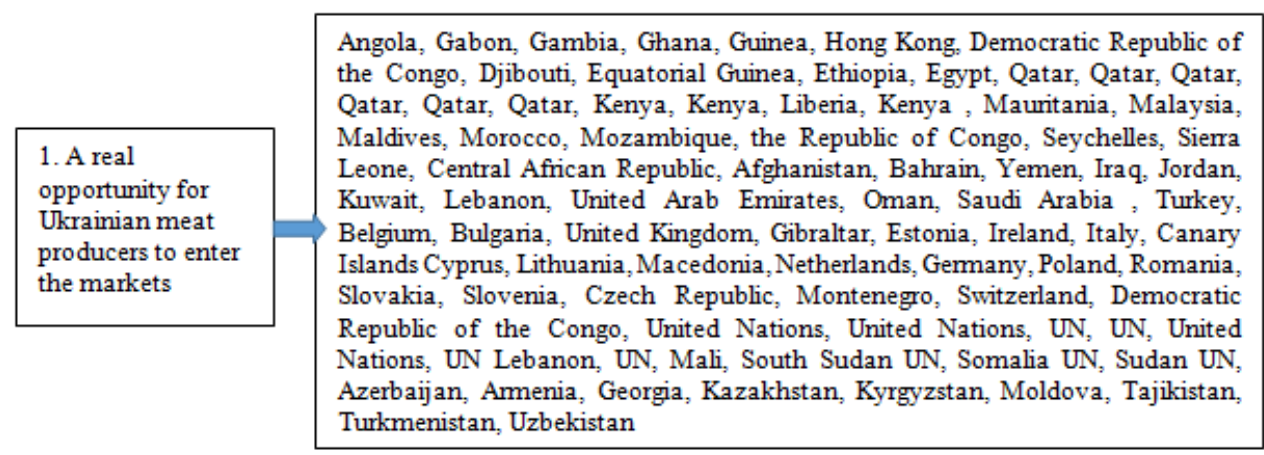

2. It is recommended that Ukrainianmeat producers study the prospects of entering new intemationalmarkets
Portugal, Slovakia, Latvia, Finland, Spain, Denmark, Jordan, Estonia, Armenia, Belarus, Austria, Malta, Greece, China

\section{Identified markets in which favorable conditions for the} release of products of Ukrainian meat producers have been created

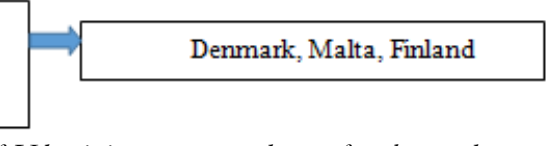

Figure 6. Marketing direction determination of the business of Ukrainian meat producers for the product group "0207 Poultry"

Source: compiled by the author

Markets of Denmark, Malta, Finland will be promising for domestic enterprises, provided they overcome a significant margin in their main indicators.

We will evaluate the conditions of entry into the international markets of Finland, Denmark and Malta of the Myronivsky Hliboproduct PJSC. Consider the dynamics of the volumes of imports of the commodity group "0207 Poultry" in these markets (Chart 15).

The analysis confirms that the markets of Finland, Denmark, Malta are import- 
dependent products of "0207 Poultry Meat", and therefore, we believe that PJSC "Myronivsky Hliboprodukt" can choose these markets of their strategies implementation for internationalization.

Chart 15. Estimation of the conditions for entering international markets for PJSC "Myronivsky Hliboproduct"

\begin{tabular}{|l|c|c|c|c|c|c|c|c|c|c|}
\hline & \multicolumn{9}{|c|}{ Volume imports of poultry meat from } & \multicolumn{5}{c|}{ Total volume of imports of poultry meat, } \\
thsd
\end{tabular}

Source: Formed by the author for (Trade Statistics for the Development of International Business) [23].

Statistics show annual consumption of poultry meat in Finland from 2007 to 2017 per capita increased. In 2017, the Finns consumed about 25 kilograms of poultry meat per capita (State Statistics Committee of Finland) (Fig. 7). The total consumption of meat, including edible offal, increased by a couple of percent in the previous year. The increase in poultry meat consumption has increased by almost nine percent since 2015 . Thus, the Finnish market may become a new market for PJSC "Myronivsky Hliboproduct".

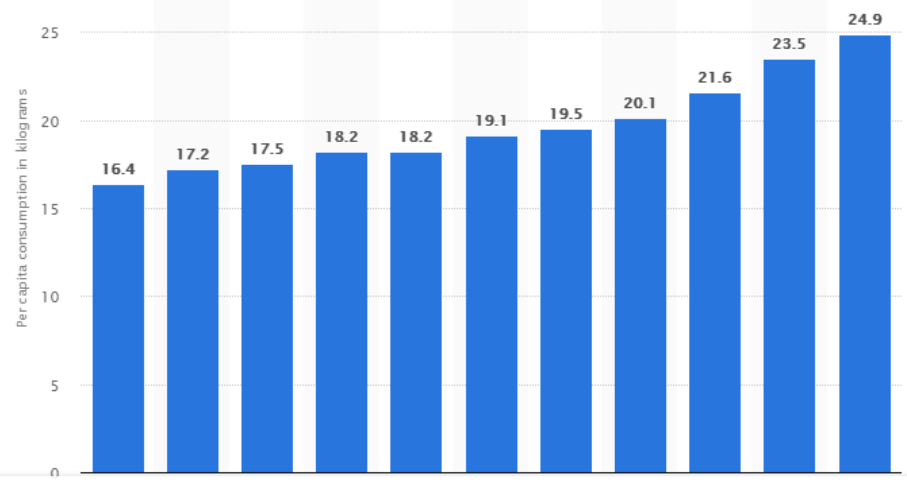

Figure 7. Dynamics of poultry meat consumption per capita in the Finnish market

Source: Formed by the author for (State Statistics Committee of Finland) [31]

Currently, poultry companies have become quite active in Denmark: they produce respectively $80 \%$ and $40 \%$ of domestic demand for poultry and eggs. However, such volumes of poultry meat production in Denmark are still not enough to meet domestic demand for consumption. Therefore, despite the passive dynamics of imports of poultry meat in the Danish market in 2015-2017, the increase in imports of poultry meat has been increased in 2018. Insignificant level of competition in this market allows us to decide that the Danish market has created conditions for the release of Ukrainian enterprises on them, in particular PJSC Myronivsky Hliboproduct (Denmark Statistics) [32]. 
There are 268 poultry farms on the Malta market. Of the total 216 farms that are on the island of Malta, the rest 52 farms are located on the neighboring islands of Gozo and Comino. The dynamics of imports is a passive one, which confirms the development of poultry farms in the domestic market of Malta over the past 2 years i.e.(Statistics of Malta) [33].

As a result of the international markets study, it was found that the markets of Finland and Denmark have shown favorable conditions for doing business on them by Ukrainian poultry producers, in particular PJSC "Myronivsky Hliboproduct". That is, the application of this approach made it possible to develop a target portfolio for further targeting the strategy implementation of internationalization by the producer of poultry meat - PJSC "Myronivsky Hliboproduct".

\section{Discussion on Future Prospects}

The most complete economic essence of international marketing reveals its definition as a philosophy and a tool of international business, as a process of developing and making decisions in the network of relationships (communications) between international firms involved in the process of commercial and non-commercial exchange of goods and services. The interaction of global and local forces forms different kinds and contents of international environment types, each of which has its own characteristics and certain forms of business. Accordingly, international marketing is expanding into specific complexes: multinational, transnational, and global.

International marketing is essentially active and offensive. It is necessary not only to study and to know the changes in the world economic situation, but also to predict its development, but also to purposefully create a favorable environment. In the framework of foreign economic relations model, the task of marketing researches of international markets was to determine the place and time of entry into the world economic arena of PJSC "Myronivsky Hliboproduct" with the commodity group "0207 Poultry", most favorable in terms of prices, sales volumes and conditions of competition.

In this study, it is determined that under the conditions of the rapid development of new industries, the strategy of internationalization should be aimed at shaping the future outlines of new markets in a direction that is beneficial for Ukrainian producers. The capture of leading positions in the emerging market (before the end is not divided and not formed) makes it possible to dictate their terms (standards, technical characteristics, prices, conditions of production and sales, the level of competitiveness) in the long run. The research has solved the actual scientific and practical task of theoretical positions substantiation and also methodical approaches to the formation of the strategy of internationalization for Ukrainian agrarian enterprises and its implementation on the new international markets, which made possible the following conclusions.

\section{Conclusion}

It is proved that under the current conditions of markets internationalization, the complex of components of an international marketing strategy proposed by us should be the basis of Ukrainian meat producers' strategic activity, in particular PJSC 
"Myronivsky Hliboproduct". As a result of its logical use, PJSC "Myronivsky Hliboproduct" will be able to increase formalization level of international marketing activities and provide a systematic and integrated approach to the planning, implementation and control of internationalization strategy in the process of entering the international market, which will enhance their competitive position in the world market. The implementation of the "Myronivsky Hliboproduct" PJSC's strategy of internationalization is the creation of a strategic marketing alliance TM "Myronivsky Hliboproduct" and TM "Qualiko" on a co-branding basis, the interrelationships within which will be built on a club basis. Participants of this club, in addition to suppliers, producers, intermediaries, partner competitors, will have loyal consumers of its products (like supporters, associates) who will want to be involved in the life of this club and really be involved in promoting their brands (distribution of products) on the domestic and international markets.

The application method of choosing a new market will allow the development of the target portfolio of PJSC "Myronivsky Hliboprodukt" for further targeting the the strategy of internationalization implementation in the markets of Finland and Denmark, which are conducive to doing business for them.

\section{Acknowledgment}

The author would like to thank Pavlenko A. F. of the KNEU named after Vadym Hetman for their help and support in making this work possible. This work might not have been possible had it not been for the efforts of the prior European Journal of Sustainable Development. Their work still lives on to some degree within European Journal of Sustainable Development.

\section{References}

[1] Golubkov, E.P. (2003), Marketing research: theory, methodology and practice. M.: Finpress, 496 p. (in Russian).

[2] Kotler F., Keller K., Pavlenko A. (2008), Marketing Management. K.: Khimzhest, 720 p.

Lukyanenko D.G., Chuzhikov V., Vozhniak Michal G. (2013), Convergence and Divergence in Europe: Polish and Ukrainian Case Studies: Monograph. Kyiv: KNEU, 688 p. (in Ukrainian).

[3] Robertson R. (2003), Globalization or glocalization. Globalisation. Critical concept in sociology. Volume III. London. pp. 31-51.

[4] Ollivie, A., Diane, A., Ource R. (1993), International Marketing. Academy Rinka: Marketing [trans. from French A. Diane, F. Buckerel, R. Lankar, et al.]. M .: Economy, 512 p.

[5] Vojchak A., Shumeiko V. (2009), Research of modern concepts of marketing and marketing management. Marketing in Ukraine. №4. pp.52-55 (in Ukrainian).

[6] Gerchikova I. N. (2000), International economic organizations: regulation of world economic relations and entrepreneurial activity. M .: Konsaltbankir, 624 p. (in Russian).

[7] PavlenkoA., Vojchak A.«Marketing». Kyiv: KNEU, 2001, 106 p.

[8] Tsigankova T. M. (2004), International Marketing: Theoretical Models and Business Technologies: Monograph. Kiev: KNEU, 137 p. (in Ukrainian).

[2] Tsigankova T. M. (2001), International Marketing Management. K.: KNEU, 132 p. (in Ukrainian).

[10] Kovinko O. ( Tanasiichuk A.) «Marketing mechanism of enterprise management in the conditions of international business diversification»: Dissertation for obtaining a scientific degree of the doctor of economic sciences. Available at: http://abstracts.donnu.edu.ua /article/view/5658/5684. 
[11] Backhaus K., Voeth M. (1996), Internationales Marketing. Stuttgart: Schaffer-Poeschel.

[12] Hoskisson R., Hitt M. (1984), Construct Validity of an Objective Categorical Measure of Diversification Strategy. New York. P. 215-235.

[13] Rumelt R. (1974), Strategy, Structure and Economic Perfomance. Cambridge. pp. 557-559.

[14] Kotler F., Berger R., Bikhoff N. (2016), Strategic Management for Kotler: Best Practices and Methods. [3rd ed.]: [Trans. from English]. M .: Alpina Business Books, 131 p.

[1ㄷ] Akulich M. V. (2006), Some Global Strategies for International Business and International Marketing. Marketing in Russia and abroad. №1, pp. 108-119 (in Russian).

[16] Sabluk P. T. (2008), World and regional production of agrarian products. K :: NTC «Institute of Agrarian Economics». 208 p. (in Ukrainian).

[17] State Committee of Statistics of Ukraine, avaible at: http: // www.ukrstat.gov.ua

[18] Agrarian news agency «Agravery», avaible at: http://agravery.com/

[19] National Agropropol «Latifundist», avaible at: http://latifundist.com/rating/top-proizvoditelejmyasnyh-produktov-2015

[20] The 5 largest agricultural companies in Ukraine by the size of the land bank, avaible at:http://economics.lb.ua/state /2016/01/13/ 325366_ 5_naybilshih_ agrokompaniy_ukraini.html.

[21] Eurasian Development Bank, avaible at: https://eabr.org /analytics/.

[22] Official site of PJSC «MHP», avaible at: http://www.mhp.com.ua/uk/home

[23] Trade statistics for international business development, avaible at: http://www.trademap.org.

[24] Global economy, avaible at: http://www.theglobaleconomy.com /rankings/happiness/

[25] World Bank Group, avaible at: http://wdi.worldbank.org/table/4.2 World Bank Group, All Rights Reserved.

[26] World Trade Organization, avaible at: https://www.wto.org /english/res_e/statis_e/its2015_e/its2015_e.pdf.

[27] Department of Agriculture of the United States. Economic Research Service, avaible at: http://www.ers.usda.gov /data-products / chart-gallery/detail.aspx?chartId= 40037.

[28] KOF Globalization Index, avaible at: http://globalization.kof.ethz.ch.

[29] AGRICISTRADE Research Project. Agriculture and trade development of the EU's eastern neighbors, avaible at: http://www.agricistrade.eu/wp-content/uploads/2015/06/Agricistrade Ukraine.pdf

[30] Worldwide Governance Indicators (RGO) draft consolidated reports and individual management indicators for 215 economies for the period 1996-2014, avaible at: http://info.worldbank.org/governance/ wgi/index.aspx\#home.

[31] State Statistics Committee of Finland, avaible at: https://www.stat.fi/index en.html

[32] Statistics of Denmark, avaible at: https://denmark.dk/

[33] Statistics of Malta, avaible at: http://www.thepoultrysite.com/poultrynews/17091/poultry -productionon-malta/ 